\title{
Een nieuw tijdperk voor abortus? Een analyse van het voorstel ter versoepeling van de Belgi- sche abortuswet
}

\author{
F. De Meyer \& C. De Mulder*
}

\section{Inleiding}

De in 2019-2020 vooropgestelde versoepeling van de Belgische Abortuswet kent een bewogen geschiedenis. Het in dit artikel besproken 'wetsvoorstel tot wijziging van diverse wetsbepalingen teneinde de voorwaarden om tot een vrijwillige zwangerschapsafbreking over te gaan te versoepelen ${ }^{1}$ bouwt voort op verschillende voorstellen ingediend gedurende de periode september tot november 2019. ${ }^{2}$ Het vertrekpunt is de Wet Vrijwillige Zwangerschapsafbreking van $2018,{ }^{3}$ die volgens sommigen vooral symbolische wijzigingen tot stand bracht. ${ }^{4}$ Hoewel een meerderheid gevormd door progressieve en liberale partijen het voorstel steunde en goedkeurde in de Commissie Justitie, kwam het op het moment van schrijven nog niet

* Fien De Meyer doet doctoraatsonderzoek naar regelgeving inzake abortus aan de Universiteit van Antwerpen. Charlotte De Mulder doet doctoraatsonderzoek naar het statuut van ongeboren leven aan de Universiteit van Antwerpen.

1 Wetsvoorstel tot versoepeling van de voorwaarden om tot een zwangerschapsafbreking over te gaan (PS), Parl.St. Kamer 2019, nr. 55-0158/1.

2 Wetsvoorstel tot wijziging van diverse wetsbepalingen teneinde vrijwillige zwangerschapsafbreking niet langer strafbaar te stellen en de uitvoeringsvoorwaarden ervan te versoepelen (DéFi), Parl.St. Kamer 2019, nr. 55-0385/1; wetsvoorstel betreffende het schrappen van abortus uit het strafrecht en het actualiseren van de wetgeving inzake vrijwillige zwangerschapsafbreking, Parl.St. Kamer 2019, nr. 55-0458/1 (PVDA-PTB); wetsvoorstel teneinde vrijwillige zwangerschapsafbreking niet langer strafbaar te stellen (Ecolo-Groen), Parl.St. Kamer 2019-20, nr. 55-0614/1; wetsvoorstel tot versoepeling van de voorwaarden om tot een zwangerschapsafbreking over te gaan (sp.a), Parl.St. Kamer 2019-20, nr. 55-676/1; wetsvoorstel betreffende vrijwillige zwangerschapsafbreking (MR), Parl.St. Kamer 2019-20, nr. 55-0740/1. Een groot deel van de wijzigingen werd bovendien reeds voorgesteld in wetsvoorstellen tussen 2016 en 2018. Zie o.m. wetsvoorstel tot wijziging van het Strafwetboek en van de wet van 22 augustus 2002 betreffende de rechten van de patiënt, teneinde vrijwillige zwangerschapsafbreking niet langer strafbaar te stellen (DéFI), Parl.St. Kamer 2015-16, nr. 54-1823/1; wetsvoorstel teneinde vrijwillige zwangerschapsafbreking uit het Strafwetboek te lichten en op te nemen in de wet van 22 augustus 2002 betreffende de rechten van de patiënt (PS), Parl.St. Kamer 2015-16, nr. 54-1867/1; wetsvoorstel betreffende de vrijwillige zwangerschapsafbreking (Ecolo-Groen), Parl.St. Kamer 2016-17, nr. 54-2271/1; wetsvoorstel betreffende het schrappen van abortus uit het strafrecht en de actualisatie van de wetgeving inzake vrijwillige zwangerschapsafbrekingen (PTB-GO!), Parl.St. Kamer 2016-17, nr. 54-2518/1.

3 Wet van 15 oktober 2018 betreffende de vrijwillige zwangerschapsafbreking, tot opheffing van de artikelen 350 en 351 van het Strafwetboek, tot wijziging van de artikelen 352 en 383 van hetzelfde Wetboek en tot wijziging van diverse wetsbepalingen, BS 29 oktober 2018.

4 T. Vansweevelt, F. De Meyer en K. Van Assche, 'De Abortuswet 2018: over symbolische verbeteringen en openstaande knelpunten', T.Gez. 2019, nr. 4, p. 220-232. 
tot een finale stemming in plenaire zitting. Tegenstanders verzetten zich immers tegen een wetsversoepeling en maakten gebruik van procedurele en politieke mechanismen om de stemming uit te stellen. ${ }^{5}$ In het recente Regeerakkoord werd beslist dat men consensus zou zoeken tussen de regeringspartijen 'binnen de commissie justitie van de Kamer, (...) en nadat een onafhankelijk multidisciplinair wetenschappelijk comité (...) een studie en evaluatie maakt van praktijk en wetgeving'. ${ }^{6}$

Hoewel het wetsvoorstel ter versoepeling van de Belgische Abortuswet hier als uitgangspunt en aanleiding wordt gebruikt, heeft de hiernavolgende analyse ook een ruimere relevantie. In deze bijdrage worden immers een aantal vraagstukken besproken waarover al geruime tijd discussie bestaat in de rechtsleer. De bespreking hiervan heeft voornamelijk tot doel duidelijkheid te scheppen in deze problematieken alsook voorstellen tot verbetering te doen, ongeacht het lot van het besproken wetsvoorstel.

Het wetsvoorstel ter versoepeling van de Abortuswet tracht verschillende wijzigingen aan te brengen aan de huidige abortuswetgeving. Het wetsvoorstel heeft als voornaamste doel ervoor te zorgen dat 'het recht op abortus' wordt versterkt. Het bestaan van een 'recht op abortus' en breder van een recht op medisch ingrijpen door een arts is echter sterk betwist. ${ }^{7}$ De voortzetting en beëindiging van de zwangerschapsafbreking vallen in ieder geval wel onder de bescherming van het recht op eerbiediging van het privéleven van de zwangere persoon, zoals beschermd door artikel 8 van het Europees Verdrag voor de Rechten van de Mens (EVRM). Hoewel hieruit geen recht op abortus kan worden afgeleid, zal wetgeving met betrekking tot vrijwillige zwangerschapsafbreking in beginsel wel raken aan het recht op eerbiediging van het privéleven van de zwangere persoon. ${ }^{8}$ In het licht hiervan vormt de abortuswetgeving in België het resultaat van een afweging tussen enerzijds het recht op eerbiediging van het privéleven van de zwangere persoon en anderzijds de bescherming van het ongeboren leven. ${ }^{9}$ De uitkomst van deze belangenafweging is

5 Tegenstanders van het wetsvoorstel vroegen vier maal juridisch advies bij de Raad van State over nieuwe amendementen. Ook waarschuwden zij dat een positieve stemming over het wetsvoorstel de lopende regeringsformatie onder druk zou zetten.

6 P. Magnette en A. De Croo, 'Verslag van de formateurs', 30 september 2020, p. 22.

7 Dit o.m. in het licht van het gewetensbezwaar van de arts.

8 Dit kan o.m. worden afgeleid uit de beslissing van de Europese Commissie voor de rechten van de mens van 13 mei 1980, nr. 8416/78, WP t. VK, § 27; hierover D. Van Grunderbeeck, Beginselen van personen-en familierecht: een mensenrechtelijke benadering, Antwerpen: Intersentia 2003, p. 364; J. Velaers, 'Het menselijk lichaam en de grondrechten' in: D. Cuypers, X. Dijon en M. Kempen, Over zichzelf beschikken? Juridische en ethische bijdragen over het leven, het lichaam en de dood, Antwerpen: Maklu 1996, p. (117) 164.

9 Zie onder de wetgeving van 1990 uitdrukkelijk: memorie van toelichting bij het voorstel van wet betreffende de zwangerschapsafbreking, strekkende om de artikelen 348, 350 en 351 van het Strafwetboek te wijzigen en de artikelen 352 en 353 van hetzelfde Wetboek op te heffen, Parl.St. Senaat BZ 1988, nr. 47-247/1, p. 7; Verslag Parl.St. Senaat BZ 1988, nr. 247/2, 21 en Parl.St. Kamer, 1989-90, nr. 950/9, p. 100 en 105; T. Vansweevelt, 'Abortus', in: T. Vansweevelt and F. Dewallens (eds.), Handboek Gezondheidsrecht. Volume II, Antwerpen: Intersentia 2014, p. 192; A. De Nauw, 'Misdaden en wanbedrijven tegen de orde der familie en de openbare zedelijkheid' in: A. De Nauw (ed.), Inleiding tot het bijzonder strafrecht, Mechelen: Kluwer 2010, p. (131) 131-132. 
afhankelijk van de heersende maatschappelijke opvattingen op het ogenblik dat de wetgeving tot stand komt. Het onderhavige wetsvoorstel legt hierbij sterk de nadruk op het zelfbeschikkingsrecht van de zwangere persoon. ${ }^{10}$

De voorgestelde wetswijziging kan, in het licht van voormelde doelstelling, worden opgedeeld in drie luiken. Ten eerste zetten de indieners van het wetsvoorstel in op de medicalisering van vrijwillige zwangerschapsafbreking door deze expliciet onder te brengen in het gezondheidsrecht. Zwangerschapsafbreking zou hierdoor worden gekwalificeerd als een medische handeling. Ten tweede worden de inhoudelijke en procedurele voorwaarden inzake vrijwillige zwangerschapsafbreking versoepeld. Daarnaast wordt een verbod op een institutionele gewetensclausule ingevoerd en wordt het misdrijf van belemmering van toegang tot de abortusinstelling uitgebreid. Ten slotte wordt vrijwillige zwangerschapsafbreking door het voorstel volledig gedepenaliseerd. De indieners van het voorstel willen hiermee verder gaan dan de Wet Vrijwillige Zwangerschapsafbreking van 15 oktober 2018, waarbij de bestaande strafbepalingen uit het Strafwetboek louter werden overgeheveld naar een bijzondere wet.

Het wetsvoorstel lijkt zowel in de praktijk als op rechtstheoretisch vlak gevolgen te zullen teweegbrengen. Zo valt te voorspellen dat in het bijzonder de wijzigingen inzake de zwangerschapstermijn, de informatieverplichtingen en de wachtperiode praktische gevolgen zullen hebben, terwijl de wijzigingen met betrekking tot de strafsancties vooral rechtstheoretisch ingrijpend zullen zijn. De volgende hoofdstukken gaan dieper in op de ratio legis, de inhoud en de potentiële gevolgen van de wijzigingen op zowel praktisch als rechtstheoretisch gebied.

\section{De medicalisering van vrijwillige zwangerschapsafbreking}

\section{- Uitbreiding van de definitie van gezondheidszorg}

Het wetsvoorstel zet allereerst in op de medicalisering van vrijwillige zwangerschapsafbreking door de ingreep uitdrukkelijk onder de definitie van 'gezondheidszorg' te brengen. Medicalisering wordt hier begrepen als de bewuste en uitdrukkelijke onderwerping van zwangerschapsafbreking aan algemene gezondheidsrechtsrechtelijke bepalingen. ${ }^{11}$ In de rechtsleer bestond reeds discussie over de kwalificatie van geneeskundige handelingen zonder therapeutisch ka-

10 Zie bv. Toelichitng bij amendement nr. 2, Parl.St. 2019-20, nr. 55-0158/3, p. 4.

11 In feministisch geïnspireerde literatuur wordt 'medicalisation' echter kritisch benaderd omdat het de politieke, sociale en persoonlijke abortuservaring zou reduceren tot iets louter medisch. Hierbij wordt de stem van de vrouw geminimaliseerd en krijgt de zorgverlener een disproportionele en soms paternalistische inmenging in de abortusbeslissing. L. Purdy, 'Women's reproductive autonomy: medicalisation and beyond', J Med Ethics 2006, 32, afl. 5, p. 287-291; S. Sheldon, Beyond control: medical power and abortion law, Londen: Pluto 1997, 213. 
rakter als gezondheidszorg en dit vooral in het kader van abortus ${ }^{12}$ en euthanasie. ${ }^{13}$ De wetgever leek er voor wat de Wet Patiëntenrechten ${ }^{14}$ betreft aanvankelijk van uit te gaan dat vrijwillige zwangerschapsafbreking niet onder de definitie van gezondheidszorg viel. ${ }^{15}$ Dit wetsvoorstel maakt aan deze discussie een einde door vrijwillige zwangerschapsafbreking uitdrukkelijk onder de definitie van gezondheidszorg te brengen. ${ }^{16}$ Hiermee wordt benadrukt dat de wetgever een evolutieve invulling wenst te geven aan wat men beschouwt als 'gezondheidszorg', waarbij wordt uitgegaan van de bevordering van het gehele fysieke, psychische en sociale welzijn van de patiënt. Een dergelijke invulling komt overeen met de definitie van gezondheid, vastgelegd door de Wereldgezondheidsorganisatie, als een toestand van volledig lichamelijk, geestelijk en sociaal welzijn en niet alleen als de afwezigheid van ziekte of gebrek. ${ }^{17}$

Het wetsvoorstel vult de definitie van gezondheidszorg uitdrukkelijk aan met vrijwillige zwangerschapsafbreking, zonder dat hierdoor noodzakelijk een verruiming plaatsvindt van het begrip 'therapeutische handeling'. Zwangerschapsafbreking wordt immers nog steeds niet beschouwd als een dienst met het oog op het bevorderen, vaststellen, behouden, herstellen of verbeteren van de gezondheidstoestand. ${ }^{18}$ De indieners van het wetsvoorstel volgen hiermee dus niet het deel van de rechtsleer dat een ruime interpretatie van het begrip 'therapeutisch doel' vooropstelde, ${ }^{19}$ maar kiezen voor dezelfde benadering die voordien werd toegepast met betrekking tot de esthetische geneeskunde ter verandering van het uiterlijk ${ }^{20}$ en de begeleiding bij het sterven. Beide zijn niet-therapeutische handelingen die eerder al onder de definitie van gezondheidszorg werden gebracht. Ook sluit de kwalifica-

12 M.-N. Veys, 'Abortus bij minderjarige en wilsonbekwame patiënten: de rol van de Wet patiënten en de noodtoestand', T. Gez. 2006-07, afl. 3, p. (153) 158 en Vansweevelt 2014, p. 225 waren reeds van oordeel dat de Wet Patiëntenrechten van toepassing was op vrijwillige zwangerschapsafbreking. Contra: H. Nys, Geneeskunde. Recht en medisch handelen in: APR, Mechelen: Kluwer 2016, p.107-108, nr. 251.

13 Hierover E. De Keyser, 'Euthanasie. Een medische handeling?', NJW 2003, nr. 45, p. (1067) 1071 die euthanasie als medische handeling beschouwt.

14 Wet van 22 augustus 2002 betreffende de rechten van de patiënt, BS 26 september 2002, err., BS 20 december 2002.

15 Zie verslag bij het wetsontwerp betreffende de rechten van de patiënt, Parl.St. Kamer 2001-02, nr. 50-1642/012, p. 53, waarin wordt vermeld dat zwangerschapsafbreking niet onder de Wet Patiëntenrechten valt. Ook orgaanwegneming en medische experimenten werden geweerd uit het begrip gezondheidszorg van de Wet Patiëntenrechten. Hierop kwam in de rechtsleer echter onmiddellijk kritiek: T. Vansweevelt, 'De Wet Patiëntenrechten. Deel I . Definities en toepassingsgebied van de Wet Patiëntenrechten', T.Gez. 2003-04, afl. 2, p. (66) 70-71; De wetgever is echter niet consistent geweest in het al dan niet onderbrengen van vrijwillige zwangerschapsafbreking onder gezondheidszorg: zie Vansweevelt 2014, 224.

16 Amendement nr. 6 Parl. St. Kamer 2019-20, nr. 55-0158/3, p. 12 en amendement nr. 11 en 12 Parl. St. Kamer 2019-20, nr. 55-0158/7, p. 6-7.

17 Preambule van the constitution of the World Health Organisation 22 juli 1946.

18 Definitie van gezondheidszorg in de Wet Patiëntenrechten (art. 2, $2^{\circ}$ Wet Patiëntenrechten). Zie ook artikel 2, $3^{\circ}$ Wet Gezondheidszorgberoepen.

19 Veys 2006-07, p. (153) 157.

20 Artikel 8 Wet van 23 mei 2013 tot regeling van de vereiste kwalificaties om ingrepen van niet-heelkundige esthetische geneeskunde en esthetische geneeskunde uit te voeren en tot regeling van de reclame en informatie betreffende die ingrepen, BS 2 juli 2013. 
tie als gezondheidszorg niet uit dat specifieke, enigszins beperkende regulering van toepassing kan blijven op vrijwillige zwangerschapsafbreking. In tegenstelling tot wat de tegenstanders van het voorstel suggereren, wordt vrijwillige zwangerschapsafbreking (alvast juridisch) niet gelijkgesteld met het trekken van een tand. ${ }^{21}$ Via een lex specialis - in casu de Wet Vrijwillige Zwangerschapsafbreking - heeft de wetgever de mogelijkheid om maatschappelijk beladen medische handelingen te onderwerpen aan strengere regels dan louter aan de algemeen gezondheidsrechtelijke bepalingen.

De uitdrukkelijke kwalificatie van vrijwillige zwangerschapsafbreking als gezondheidszorg leidt nu tot een zekere stroomlijning ten opzichte van andere medische handelingen. Door het wetsvoorstel wordt het nu onbetwist dat een zwangere persoon zich zal kunnen beroepen op de rechten gewaarborgd door de Wet Patiëntenrechten, waarbij de geïnformeerde toestemming en het klachtrecht centraal staan. Ook zal kwaliteitsvolle zorg worden gegarandeerd door de Wet Patiëntenrechten en de verdere uitwerking hiervan in de Kwaliteitswet. ${ }^{22}$ Die laatste wet werd van kracht op 1 juli $2021^{23}$ en heeft onder meer betrekking op de diagnostische en therapeutische vrijheid van de gezondheidszorgbeoefenaar, diens bekwaamheid, de omkadering en continuïteit van de gezondheidszorg, en de structuur en organisatie van de praktijkvoering. Ten slotte garandeert de Gezondheidszorgberoepenwet $^{24}$ tevens de bekwaamheid van de gezondheidszorgbeoefenaar, door onder meer voorwaarden te stellen inzake diploma's en beroepstitels.

Voormelde gezondheidswetten zijn echter slechts van toepassing voor zover de Wet Vrijwillige Zwangerschapsafbreking geen afwijkende regeling bevat. ${ }^{25}$ De bijzondere afwijkende voorwaarden in de Wet Vrijwillige Zwangerschapsafbreking blijven onverkort gelden, maar worden aangevuld en geïnterpreteerd in het licht van algemene gezondheidswetten, zoals de Wet Patiëntenrechten. ${ }^{26}$ Dit geldt ook voor andere gezondheidswetten, zoals de Wet medisch begeleide voortplanting (MBV-wet): ${ }^{27}$ de Wet Patiëntenrechten blijft integraal van toepassing als lex generalis. ${ }^{28}$ In bepaalde gevallen is het echter niet duidelijk of de Wet Vrijwillige Zwangerschapsafbreking een afwijkende regeling bevat. Dit is in het bijzonder zo met betrekking tot de vereiste van verzoek en toestemming tot vrijwillige

21 Opinie V. Van Peel en B. De Wever 'De roekeloosheid van dit hele schouwspel is niet minder dan een schande', De Morgen, 13 juli 2020.

22 Wet van 22 april 2019 inzake de kwaliteitsvolle praktijkvoering in de gezondheidszorg, BS 14 mei 2019.

23 Artikel 88 Kwaliteitswet.

24 Wet van 10 mei 2015 betreffende de uitoefening van de gezondheidszorgberoepen, gecoördineerd op 10 mei 2015, BS 18 juni 2015.

25 De Wet Vrijwillige Zwangerschapsafbreking heeft als lex specialis immers voorrang op de Wet Patientenrechten; A. Dierickx, Toestemming en strafrecht, Antwerpen: Intersentia 2006, p. 361; Delbeke 2012 p. 207.

26 M.-N. Veys 2006-07, p. (153) 157.

27 Wet van 6 juli 2007 betreffende de medisch begeleide voortplanting en de bestemming van de overtallige embryo's en de gameten, BS 17 juli 2007.

28 H. Nys en T. Wuyts, 'De wet betreffende de medisch begeleide voortplanting en de bestemming van de overtallige embryo's en de gameten', RW 2008, nr. 19, p. (762) 762. Dit wordt uitdrukkelijk bevestigd in het advies van de Raad van State bij de MBV wet: Advies RvS van 14 februari 2006 nrs. 39.474/AV tot 39.478/AV en 39.525/AV, Parl. St. Senaat 2005-06, nr. 3-417/3, p. 84-85, nr. 154. 
zwangerschapsafbreking. De Wet Vrijwillige Zwangerschapsafbreking vermeldt uitdrukkelijk dat 'de zwangere vrouw' de zwangerschapsafbreking mag verzoeken en hiertoe schriftelijke toestemming moet geven. Hierdoor zou het onduidelijk kunnen zijn of de vertegenwoordigingsregels in de Wet Patiëntenrechten met betrekking tot wilsonbekwaamheid en minderjarigheid worden uitgesloten.

\subsection{Zwangerschapsafbreking bij minderjarigen en wilsonbekwamen}

De Wet Patiëntenrechten voorziet in een regeling met betrekking tot de uitoefening van patiëntenrechten door minderjarige (art. 12 Wet patiëntenrechten) en wilsonbekwame meerderjarige (art. 14 Wet Patiëntenrechten) patiënten. Wilsonbekwaamheid heeft betrekking op de feitelijke onmogelijkheid van een persoon om zijn wil te vormen of te uiten en moet onderscheiden worden van handelingsonbekwaamheid. Handelingsonbekwaamheid is de juridische onmogelijkheid om bepaalde rechtshandelingen te stellen. ${ }^{29}$ Anders dan bij handelingsonbekwaamheid, wat een abstracte wijziging van de rechtstoestand van een persoon veronderstelt, dient bij wilsonbekwaamheid steeds een in concreto oordeel te worden gevormd over de mogelijkheid voor de betrokkene om wetens en willens bepaalde rechten uit te oefenen of bepaalde plichten op zich te nemen. ${ }^{30}$ Zowel voor minderjarigen als wilsonbekwame meerderjarigen bevat de Wet Patiëntenrechten een cascaderegeling met het oog op vertegenwoordiging bij het uitoefenen van de rechten onder deze wet, waaronder dus ook het geven van geïnformeerde toestemming (art. 8 Wet Patiëntenrechten).

Over de vraag of de regeling in de Wet Patiëntenrechten ook van toepassing is op vrijwillige zwangerschapsafbreking bestaat echter al geruime tijd discussie. ${ }^{31} \mathrm{De}$ Wet Vrijwillige Zwangerschapsafbreking vermeldt hierover niets, maar vereist, zoals vermeld, dat de zwangere persoon om de zwangerschapsafbreking verzoekt en hiervoor schriftelijke toestemming geeft (art. 2, eerste lid Wet Vrijwillige Zwangerschapsafbreking).

De toestemming door en vertegenwoordiging van minderjarige en wilsonbekwame zwangere personen kwam tijdens de voorbereidende werken bij de Wet Vrijwillige Zwangerschapsafbreking van 2018 en die bij het huidig wetsvoorstel niet aan bod. Enkel bij de totstandkoming van de Wet zwangerschapsafbreking van 1990 rees kort de vraag of de ouder(s) van een minderjarige moet(en) worden ingelicht over de voorgenomen zwangerschapsafbreking en/of toestemming moet(en) geven. ${ }^{32}$ Hierop werd echter geen duidelijk antwoord geboden. De wetgever leek er bij de totstandkoming van voormelde wet wel van uit te gaan dat de toestemming van de minderjarige zelf in ieder geval is vereist, door aan te halen dat het voorstel voorziet in geen enkel uitsluitsel gebaseerd op leeftijd. ${ }^{33}$ Over zwangerschapsafbreking bij wilsonbekwamen vermelden de voorbereidende werken niets. De vraag werd bij

\section{F. Swennen 2021 p. 163.}

Zie voor een weergave van de verschillende standpunten in dit debat: Vansweevelt 2014, p. 230-238; zie m.b.t. minderjarigen ook Nys 2016, p. 266, nr. 514.

Verslag Parl.St. Senaat BZ 1988, nr. 247/2, p. 134-136.

Verslag Parl.St. Senaat BZ 1988, nr. 247/2, p. 137. 
de bespreking van de Wet zwangerschapsafbreking van 1990 wel gesteld in de Senaatscommissie, maar werd niet beantwoord. ${ }^{34}$

Over de vraag of minderjarigen en wilsonbekwamen de zwangerschapsafbreking steeds zelf moeten (of kunnen) vragen, dan wel vertegenwoordigd kunnen (of moeten) worden, zijn verschillende standpunten mogelijk. Enerzijds kan worden beargumenteerd dat de Wet Vrijwillige Zwangerschapsafbreking vereist dat enkel de zwangere persoon om zwangerschapsafbreking kan verzoeken en hiermee kan toestemmen. ${ }^{35}$ De Wet Vrijwillige Zwangerschapsafbreking zou vanuit deze redenering dus een van de Wet Patiëntenrechten afwijkende regeling bevatten en deze hierdoor uitsluiten. Vertegenwoordiging bij wilsonbekwaamheid zou hierdoor echter nooit mogelijk zijn, waardoor in dit geval geen zwangerschapsafbreking kan plaatsvinden. Voor wilsbekwame minderjarigen blijft de situatie onduidelijk, maar op grond van de voorbereidende werken kan worden aangenomen dat zwangerschapsafbreking mogelijk is. ${ }^{36}$ Anderzijds wordt door verschillende auteurs aangenomen dat gelet op de afwezigheid van een duidelijke regeling in de Wet Vrijwillige Zwangerschapsafbreking, de regeling in de Wet Patiëntenrechten onverkort van toepassing is. ${ }^{37}$ Aangezien moeilijk kan worden aangenomen dat de wetgever elke mogelijkheid tot vrijwillige zwangerschapsafbreking voor wilsonbekwame personen heeft willen uitsluiten, verdient o.i. de tweede opvatting de voorkeur. Dit standpunt zou ook worden bevestigd door het uitdrukkelijk onderbrengen van vrijwillige zwangerschapsafbreking onder het toepassingsgebied van de Wet Patientenrechten, zoals het wetsvoorstel wil invoeren. Aangezien deze wet, in tegenstelling tot de Wet Vrijwillige Zwangerschapsafbreking, wel een duidelijke regeling bevat, moet deze hier als algemene wet toepassing krijgen. Of dit in alle gevallen tot een wenselijke oplossing zal leiden, wordt hierna verder onderzocht.

Voor minderjarigen geldt dat de rechten vastgesteld onder de Wet Patiëntenrechten worden uitgeoefend door de ouders die het gezag over de minderjarige uitoefenen of door hun voogd (art. 12, §1 Wet Patiëntenrechten). De minderjarige moet evenwel worden betrokken bij de uitoefening van zijn rechten, rekening houdend met zijn leeftijd en maturiteit. Indien de minderjarige tot een redelijke beoordeling van zijn belangen in staat kan worden geacht, kan deze de rechten onder de Wet Patiëntenrechten zelfstandig uitoefenen. Hieruit volgt volgens een deel van de rechtsleer dat de wilsbekwame minderjarige zelf en zelfstandig zijn rechten onder de Wet Patiëntenrechten kan uitoefenen en in het licht hiervan ook om een zwangerschapsafbreking kan verzoeken zonder dat de ouders bij deze beslissing worden

34 Verslag Parl.St. Senaat BZ 1988, nr. 247/2, p. 117-118; de spreker vermeldt hier verkeerdelijk het begrip rechtsbekwaam; Veys 2006-07, p. (153) 159.

35 Dat enkel de zwangere persoon toestemming kan geven wordt ook afgeleid uit artikel 348 Sw. op grond waarvan een vruchtafdrijving bij een zwangere persoon die daarin zelf niet heeft toegestemd, stafbaar is; Nys 2016, p. 226, nr. 514.

36 Veys 2006-07, p. 163.

37 Zie o.a. Vansweevelt 2014, p. 235; Veys 2006-07, p. 163. 
betrokken. ${ }^{38}$ Op het belang van de mogelijkheid voor wilsbekwame minderjarigen om zonder inmenging van de ouders om een vrijwillige zwangerschapsafbreking te verzoeken, werd ook tijdens de besprekingen bij de Wet zwangerschapsafbreking 1990 gewezen. ${ }^{39}$ Ook het Grondwettelijk Hof (toen nog Arbitragehof) lijkt in het licht van het gelijkheidsbeginsel geen probleem te zien in de mogelijkheid voor een minderjarige om over te gaan tot vrijwillige zwangerschapsafbreking zonder dat de ouders hierbij worden geraadpleegd of toegang hebben tot een rechtbank. ${ }^{40}$ In de praktijk wordt - o.i. terecht - aanvaard dat minderjarigen zonder tussenkomst van de ouders om een zwangerschapsafbreking kunnen verzoeken, op voorwaarde dat zij over voldoende maturiteit beschikken om een dergelijke beslissing te nemen. ${ }^{41}$

Voor wilsonbekwame meerderjarige patiënten bevat artikel 14 Wet Patiëntenrechten een cascaderegeling. Patiëntenrechten worden in de eerste plaats uitgeoefend door de persoon die de patiënt hiertoe vooraf heeft aangewezen. Heeft een dergelijke aanwijzing niet plaatsgevonden, dan worden de rechten uitgeoefend door de bewindvoerder die door de vrederechter overeenkomstig artikel 492/1, §1, vierde lid oud BW werd aangewezen. Indien geen bewindvoerder bevoegd is om de wilsonbekwame patiënt te vertegenwoordigen, dan worden de rechten in opeenvolgende volgorde uitgeoefend door de samenwonende echtgenoot, wettelijk of feitelijk samenwonende partner (art. 14, §3, eerste lid Wet Patiëntenrechten), een meerderjarig kind, een ouder, een meerderjarige broer of zus van de patiënt (art. 14, § 3, tweede lid Wet Patiëntenrechten) of bij gebreke hiervan en in geval van conflict, de betrokken beroepsbeoefenaar (art. 14, § 3, derde lid Wet Patiëntenrechten). ${ }^{42}$

De toepassing van de vertegenwoordigingsregels uit de Wet Patiëntenrechten op zwangerschapsafbreking bij wilsonbekwame personen is echter niet volledig afgestemd op de wetgeving inzake meerderjarige beschermde personen. ${ }^{43}$ Op grond van artikel $497 / 2$, $19^{\circ}$ oud BW is het verzoek tot vrijwillige zwangerschapsafbreking niet vatbaar voor bijstand of vertegenwoordiging door de bewindvoerder. Op dit vertegenwoordigingsverbod kwam in de rechtsleer al geruime tijd kritiek, aangezien dit zou leiden tot de onmogelijkheid voor personen onder rechterlijke bescherming om de zwangerschap af te breken. ${ }^{44}$ Aanvankelijk werd door sommigen

Veys 2006-07, p. (153) 159; Vansweevelt 2014, p. 237; zie ook wetsontwerp betreffende de rechten van de patiënt, Parl.St. Kamer 2001-02, nr. 50-1642/1, p. 40; zie algemeen over de rechten van wilsbekwame minderjarigen onder de Wet Patiëntenrechten: C. Lemmens, 'De handelings-en wilsonbekwamen' in: T. Vansweevelt and F. Dewallens (eds.), Handboek Gezondheidsrecht. Volume II, Antwerpen: Intersentia 2014, p. 847 e.v.

39 Verslag Parl.St. Senaat BZ 1988, nr. 247/2, p. 136-137.

40 Arbitragehof nr. 39/91, 19 december 1991, nr. 6.B.17.

41 Zie bv. www.abortus.be/_nl/overabortus/wet_bepalingen.php en www.kennisplein.be/sites/ Jeugdrecht/Pages/2017-03-ONGEPLAND-ZWANGER-ABORTUS.aspx.

42 In dit laatste geval is echter geen sprake van vertegenwoordiging; hierover: H. Nys, 'De ontwikkeling van het gezondheidsrecht in 2007 en 2008', T. Gez. 2009-10, afl. 3, p. (87) 102-103.

43 Zie hieraan gerelateerd over de tegenstrijdigheid tussen de vertegenwoordigingsregels van artikel 14 Wet Patiëntenrechten en artikel 497/2, 15 oud BW op grond waarvan het verlenen van toestemming tot sterilisatie niet vatbaar is voor vertgenwoordiging door de bewindvoerder: Orde der artsen, Advies over de sterilisatie met contraceptief doel van een mentaal gestoorde persoon, 15 november 2014.

44 F. Swennen, 'De meerderjarige beschermde personen (Deel II)', RW 2013-14, nr. 16, p. (602) 609. 
ook aangenomen dat de wetgever de bedoeling heeft gehad om de reeks strikt persoonlijke handelingen in artikel 497/2 oud BW nooit vatbaar te maken voor vertegenwoordiging en dus ook niet door andere (informele) vertegenwoordigers dan de bewindvoerder in het kader van rechterlijke bescherming. ${ }^{45}$ Dit standpunt is thans niet langer houdbaar in het licht van het in 2018 gewijzigde artikel 497/2 oud BW. ${ }^{46}$ Het eerste lid vermeldt nu immers dat de in deze bepalingen vermelde handelingen, waaronder dus ook het verzoek tot vrijwillige zwangerschapsafbreking, niet vatbaar zijn voor vertegenwoordiging in zoverre de beschermde persoon daarvoor handelingsonbekwaam werd verklaard.

De vraag rijst of het mogelijk is om door de vrederechter handelingsonbekwaam te worden verklaard om een zwangerschapsafbreking te vragen. Aangezien artikel 492/1, § 1 oud BW hierover niets vermeldt, moet de vrederechter zich hierover in ieder geval niet uitspreken. ${ }^{47}$ In de rechtsleer bestaat echter onenigheid over de vraag of de rechter personen voor een dergelijke strikte persoonlijke handeling wel handelingsonbekwaam kan verklaren. ${ }^{48}$ Een deel van de rechtsleer neemt immers aan dat het voor het verzoek tot vrijwillige zwangerschapsafbreking enkel mogelijk is om ad hoc wilsonbekwaam te worden verklaard. ${ }^{49}$ Dit verdient aanbeveling, aangezien een abstracte onbekwaamheid onvoldoende waarborgen zou bieden in het licht van de bescherming van het recht op eerbiediging van het privéleven, waaronder ook de beslissing valt om de zwangerschap al dan niet voort te zetten. ${ }^{50}$

Het onderbrengen van vrijwillige zwangerschapsafbreking onder de Wet Patiëntenrechten bevestigt dit standpunt, aangezien de vrederechter de meerderjarige beschermde persoon niet langer handelingsonbekwaam kan verklaren voor de uitoefening van de rechten onder deze wet. De vrederechter dient zich bij het opleggen van een beschermingsmaatregel aan een meerderjarige persoon thans enkel uit te spreken over de bevoegdheid van de bewindvoerder om de rechten van de patiënt uit te oefenen op basis van artikel 14, § 2 Wet Patiëntenrechten voor het geval die deze op grond van voormelde wet niet meer zelf kan uitoefenen (art. 492/1, §1, laatste lid BW). Aanvankelijk moest de rechter zich ook uitspreken over de bekwaamheid voor de uitoefening van de patiëntenrechten. Deze mogelijkheid werd met de Wet van 21 december 2018 geschrapt, ${ }^{51}$ aangezien dit niet in overeenstemming is met de Wet Patiëntenrechten. Het in concreto oordeel van de

45 T. Opgenhaffen, Vrijheidsbeperkingen in de zorg, Antwerpen: Intersentia 2020, p. 149.

46 Zie artikel 17 a) Wet van 21 december 2018 houdende diverse bepalingen betreffende justitie, BS 31 december 2018.

47 Het gebrek aan overeenstemming tussen de checklist van artikel 492/1 oud BW en de lijst van hoogstpersoonlijke handelingen in artikel 497/2 oud BW wordt bekritiseerd gelet op de onzekerheid die hiermee wordt gecreëerd; S. Mosselmans en A. Van Thienen, "Bescherming en bewind voor meerderjarigen. Commentaar bij de wet van 17 maart 2013”, T.Fam. 2014, p. (60) 81.

48 T. Opgenhaffen 2020, p. 129.

49 F. Swennen, 'De meerderjarige beschermde personen (Deel I)', RW 2013-14, nr. 16, p. (563) 574.

50 Hierover in het licht van het Amerikaanse veertiende amendement: M. Ditkowsky, 'Choice at risk: the threat of adult guardianship to substantive and procedural due process rights in reproductive health', National Lawyers Guild Review 2019, nr. 76, p. (92) 100.

51 Zie art. 11 a) Wet van 21 december 2018 houdende diverse bepalingen betreffende justitie, BS 31 december 2018. 
arts over de vraag of de patiënt in staat is zijn rechten uit te oefenen, moest immers steeds voorgaan op de door de rechter uitgesproken handelings(on)bekwaamheid. ${ }^{52}$ Van belang hierbij is dus voormeld onderscheid tussen handelingsonbekwaamheid en wilsonbekwaamheid. De bepalingen in het Oud Burgerlijk Wetboek met betrekking tot rechterlijke bescherming hebben steeds betrekking op handelingsonbekwaamheid en dus op de juridische onmogelijkheid om zelf en zelfstandig rechten uit te oefenen. De Wet Patiëntenrechten gaat daarentegen uit van wils(on) bekwaamheid (art. 14, 1 , eerste lid Wet Patiëntenrechten). Aangezien de arts op grond van de Wet Patiëntenrechten oordeelt of een persoon wilsbekwaam is om de rechten onder deze wet uit te oefenen, ${ }^{53}$ komt het de vrederechter niet toe te oordelen over de handelingsbekwaamheid van de te beschermen persoon. ${ }^{54}$ Indien vrijwillige zwangerschapsafbreking uitdrukkelijk onder de Wet Patiëntenrechten wordt gebracht, moet worden aangenomen dat de vrederechter zich ook niet kan uitspreken over de bekwaamheid om een vrijwillige zwangerschapsafbreking te vragen, waardoor artikel 497/2, $19^{\circ}$ oud BW zonder voorwerp is. Een aanpassing van deze bepaling is dan ook aangewezen.

Hoewel vertegenwoordiging van wilsonbekwame personen bij het verzoek tot vrijwillige zwangerschapsafbreking o.i. mogelijk is, rijzen niettemin vragen met betrekking tot de verenigbaarheid hiervan met het recht op eerbiediging van het privéleven (art. 8 EVRM) en het VN-Verdrag inzake de Rechten van Personen met een Handicap (VRPH). Vooral in het licht van dit laatste lijkt het verbod op gedwongen abortus $^{55}$ te worden uitgebreid naar een verbod op abortus door plaatsvervangende toestemming tegen de wil in van de betrokkene. ${ }^{56}$ Een gelijkaardige bezorgdheid wordt geuit in verband met sterilisatie van wilsonbekwame personen. ${ }^{57}$ Een abortus mag in beginsel nooit plaatsvinden zonder dat de betrokkene hiertoe diens geïnformeerde toestemming heeft gegeven. ${ }^{58}$ Van gedwongen abortus kan dan ook sprake zijn wanneer de zwangerschapsafbreking plaatsvindt na een beslissing ge-

52 Opgenhaffen 2020, p. 122; T. Wuyts, 'Het eengemaakte beschermingsstatuut voor wilsonbekwamen hervormd. Commentaar bij de wet van 21 december 2018' in: T. Wuyts, T. Van Halteren and L. Speltincx (eds.), Onbekwame meerderjarigen: aanpassingen van de wet van 2013 - Openbare verkoop: biddit, de onlineprocedure, Brugge: die Keure 2019, p. 13; D. Scheers en C. Scheers, 'Bescherming van meerderjarige onbekwamen: op maat van de praktijk (Deel I)', RW 2018-19, nr. 39, p. (1522) 1525.

53 Wetsontwerp betreffende de rechten van de patiënt, Parl.St. Kamer 2001-02, nr. 50-1642/1, p. 41.

54 Memorie van toelichting bij het wetsontwerp houdende diverse bepalingen inzake burgerlijk recht en tot vereenvoudiging van de bepalingen van het Burgerlijk Wetboek en het Gerechtelijk Wetboek betreffende de onbekwaamheid, en van de wet van 17 maart 2013 tot hervorming van de regelingen inzake onbekwaamheid en tot instelling van een nieuwe beschermingsstatus die strookt met de menselijke waardigheid, Parl.St. Kamer 2017-18, nr. 54-3303/1, p. 26.

55 Recommendation CM/Rec (2012)6 of the Committee of Ministers to member States on the protection and promotion of the rights of women and girls with disabilities, 13 juni 2012, CM/Rec (2012)6, p. 8; Report of the Office of the United Nations High Commissioner for Human Rights on the Issue of Violence against Women and Girls and Disability, 30 maart 2012, Un Doc. A/HRC/20/5, $\S 29$.

56 Opgenhaffen 2020, p. 150.

57 Concluding observations of the Committee on Economic, Social and Cultural Rights on the sixth periodic report of Finland, E/c.12/FIN/CO/6, § 26.

58 General Comment no. 5 of the Committee on Economic, Social and Cultural Rights on Persons with Disabilities, 9 december 1994, UN. Doc. E/1995/22, § 31. 
nomen door de vertegenwoordiger in overeenstemming met de wettelijke procedures, maar tegen de wil in van de zwangere persoon met een beperking. ${ }^{59}$ Aan staten wordt dan aanbevolen om te voorzien in effectieve waarborgen ter bescherming van de rechten van personen met een beperking via een model van ondersteuning bij ieder beslissingsproces dat verband houdt met seksuele of reproductieve gezondheid. ${ }^{60}$ Van belang hierbij is dat de wilsonbekwame zwangere persoon voor zover mogelijk de beslissing zelf kan nemen en hierbij de nodige ondersteuning en voorlichting krijgt. ${ }^{61}$

Dit laatste komt in België reeds tot uiting in de Wet Patiëntenrechten. Op grond van artikel 14, $\S 4$ moet de patiënt zo veel mogelijk en in verhouding tot zijn begripsvermogen worden betrokken bij de uitoefening van zijn rechten. Het begripsvermogen van de patiënt is dus bepalend voor de mate waarin rekening wordt gehouden met diens wensen en/of het verzet met betrekking tot de zwangerschapsafbreking. ${ }^{62}$ Hoe deze vereiste precies moet worden ingevuld blijkt niet duidelijk uit de wet. ${ }^{63}$ Verzet door een wilsonbekwame zwangere persoon specifiek gericht tegen de zwangerschapsafbreking zal in het licht van voormelde verdragen in beginsel moeten worden gerespecteerd. Het verrichten van een abortus zonder de zwangere persoon in verhouding tot diens begripsvermogen bij de beslissing te betrekken en dus zonder rekening te houden met diens wens om de zwangerschap uit te dragen, zou bij gebrek aan geldige toestemming overigens ook strafbaar kunnen zijn onder artikel 348 Sw. dat betrekking heeft op vruchtafdrijving zonder de toestemming van de zwangere persoon. ${ }^{64}$

De zwangerschapsafbreking zal ondanks het verzet van de wilsonbekwame persoon toch mogelijk zijn indien er sprake is van ernstige therapeutische redenen die de abortus rechtvaardigen. ${ }^{65}$ Het uitgangspunt hierbij blijft dat de vertegenwoordiger rekening moet houden met de wens van de wilsonbekwame persoon om het kind te houden, tenzij de zwangerschap de gezondheid van de zwangere persoon

59 Report of the Special Rapporteur on torture and other cruel, inhuman or degrading treatment or punishment on the promotion and protection of all human rights, civil, political, economic, social and cultural rights, including the right to development, 15 januari 2008. UN.Doc. A/HRC/7/3, § 38; Concluding observations of the Committee on the Rights of persons with Disabilities on the initial report of Argentina as approved by the Committee at its eighth session (17-28 september 2012), 8 oktober 2012, UN.Doc. CRPD/C/ARG/CO/1, §§31-32; Concluding observations of the Committee on the Rights of Persons with Disabilities on the initial report of Germany, 13 mei 2015, CRPD/C/ $\mathrm{DEU} / \mathrm{CO} / 1, \S 37$.

60 Concluding observations of the Committee on Economic, Social and Cultural Rights on the sixth periodic report of Finland, E/c.12/FIN/CO/6, § 26.

61 Concluding observations of the Committee on the Rights of persons with Disabilities on the initial report of Argentina as approved by the Committee at its eighth session (17-28 september 2012), 8 oktober 2012, UN.Doc. CRPD/C/ARG/CO/1, §§ 31-32; General comment No. 3 (2016) of the Committee on the Rights of Persons with Disabilities, 25 november 2016, UN.Doc. CRPD/C/GC/3, $\S 32 ; \S \S 40 ; 44$.

62 Veys 2006-07, p. (153) 160; Vansweevelt 2014, p. 231.

63 Opgenhaffen 2020, p. 141.

64 Artikel 348 Sw. stelt strafbaar eenieder die door enig middel opzettelijk vruchtafdrijving een vrouw veroorzaakt die daarin niet heeft toegestemd.

65 Veys 2006-07, p. (153) 160. 
bedreigt. ${ }^{66}$ Naast complicaties door de zwangerschap zelf, wordt hiermee volgens VEYS ook de situatie beoogd waarbij de zwangere persoon niet langer de nodige medicatie kan innemen door zwangerschapsbraken of wanneer de zwangerschap leidt tot neigingen van zelfdestructie. ${ }^{67}$ Zowel ernstige bedreigingen voor de fysieke als voor de mentale gezondheid komen hierbij dus in aanmerking. Aangezien de keuze voor het voortzetten of afbreken van de zwangerschap een essentieel onderdeel vormt van het privéleven van de zwangere persoon, is grote terughoudendheid o.i. steeds geboden.

Het voorgaande neemt niet weg dat het in bepaalde gevallen onduidelijk zal zijn op grond van welke overwegingen de vertegenwoordiger of eventueel de $\operatorname{arts}^{68}$ de beslissing tot zwangerschapsafbreking bij een wilsonbekwame persoon moet beoordelen. Wanneer het onmogelijk is om de uitdrukkelijke, dan wel de vermoedelijke wil van de patiënt hierover te kennen, zal de beslissing moeten worden genomen in het belang van de patiënt. ${ }^{69}$ Of een zwangerschapsafbreking in het belang is van de betrokkene is echter niet eenvoudig te bepalen. In het bijzonder bij een zwangerschapsafbreking zonder maternale of foetale indicatie, zal het vrijwel onmogelijk zijn om aan de hand van objectieve maatstaven te beoordelen of de zwangerschapsafbreking al dan niet in het belang is van de wilsonbekwame patiënt. De beoordeling zal hier dus geval per geval moeten gebeuren, rekening houdend met alle concrete omstandigheden. Of hierbij ook rekening mag worden gehouden met 'het belang' van de foetus of het potentieel toekomstig geboren kind is thans onzeker. In dit verband stelt VEYS dat bij een vergelijking tussen zwangerschapsafbreking bij wilsonbekwame personen enerzijds en sterilisatie bij wilsonbekwame personen anderzijds voor ogen moet worden gehouden dat bij een zwangerschapsafbreking, buiten de aantasting van de fysieke integriteit van de onbekwame persoon, ook rekening wordt gehouden met de bescherming van het ongeboren leven. ${ }^{70}$ Dit laatste uit zich echter al in de voorwaarden gesteld door de Wet Vrijwillige Zwangerschapsafbreking, welke uiteraard ook bij zwangerschapsafbreking bij wilsonbekwame personen moeten worden gerespecteerd.

De wetgever zou er o.i. in ieder geval goed aan doen om de verhouding van de Wet Vrijwillige Zwangerschapsafbreking tot de regeling in de Wet Patiëntenrechten rond medische handelingen bij minderjarige en wilsonbekwame meerderjarige patiënten uitdrukkelijk te regelen. Het verdient hierbij aanbeveling dat de wetgever in de Wet Vrijwillige Zwangerschapsafbreking uitdrukkelijk aanknoopt bij het criterium van wilsbekwaamheid en dit zowel voor minderjarige als meerderjarige personen. Net zoals het geval is onder de Wet Patiëntenrechten kan de aanwezigheid van wilsbekwaamheid worden beoordeeld door de arts. Dit zou voor wilsbekwame

Veys 2006-07, p. (153) 160; hierbij wordt een impliciete grondslag gezocht in artikel 15, 2 Wet Patiëntenrechten. Op grond hiervan kan de betrokken beroepsbeoefenaar in het belang van de patiënt en teneinde een bedreiging van diens leven of een ernstige aantasting van diens gezondheid af te wenden, afwijken van de beslissing van de vertegenwoordiger.

67 Veys 2006-07, p. (153) 160.

68 In dit geval op grond van artikel 14, § 3 of artikel 15, § 2 Wet Patiëntenrechten.

69 Hierover algemeen Lemmens 2014, p. 966-968.

70 Veys 2006-07, p. (153) 159. 
minderjarigen de huidige praktijk bevestigen waarbij de wilsbekwame minderjarige patiënt zelf en zelfstandig om de zwangerschapsafbreking kan verzoeken, zonder dat de ouders of voogd hierover moeten worden ingelicht. Voor wilsonbekwame minderjarigen kan verder een uitdrukkelijke verwijzing naar de regeling in artikel 12 Wet Patiëntenrechten dienstig zijn. Een wetswijziging zou echter vooral duidelijkheid kunnen scheppen voor wilsonbekwame meerderjarige zwangere personen. Hierbij is o.i. een uitdrukkelijke verwijzing naar de cascaderegeling in artikel 14 Wet Patiëntenrechten wenselijk. Deze regeling moet, zoals vermeld, ook zonder bijkomende wetswijziging reeds toepassing vinden. Vrijwillige zwangerschapsafbreking valt (door het wetsvoorstel) immers onder de Wet Patiëntenrechten. Deze laatste moet worden toegepast aangezien de Wet Vrijwillige Zwangerschapsafbreking geen bijzondere regeling bevat. Niettemin is een uitdrukkelijke verwijzing in deze wet aangewezen aangezien hierdoor iedere twijfel wordt weggenomen en een meer rechtszekere situatie wordt gecreëerd.

\section{Versoepeling van de voorwaarden bij vrijwillige zwangerschapsafbreking}

\subsection{Zwangerschapstermijn}

\subsubsection{Verlenging}

Het wetsvoorstel heeft tot doel om de substantiële zwangerschapstermijn van twaalf weken in artikel $2,1^{\circ}$ a) Wet Vrijwillige Zwangerschapsafbreking op te trekken naar achttien weken. Vóór achttien weken zwangerschap zal zwangerschapsafbreking mogelijk zijn op verzoek van de zwangere persoon, zonder dat aan bijkomende inhoudelijke voorwaarden moet zijn voldaan.

De uitbreiding van de zwangerschapstermijn is voornamelijk ingegeven door de vaststelling dat jaarlijks ongeveer 500 personen genoodzaakt zijn om een zwangerschapsafbreking in het buitenland, gewoonlijk Nederland ${ }^{71}$ of het Verenigd Koninkrijk, te verzoeken omdat zij de twaalfwekentermijn voorbij zijn. Om aan de noden van deze personen tegemoet te komen, wensen de indieners de termijn met zes weken te verlengen. ${ }^{72}$ Verder wordt met de verlenging van de termijn getracht om tegemoet te komen aan de wensen van de abortuscentra. ${ }^{73} \mathrm{Zij}$ zouden namelijk geregeld worden geconfronteerd met verzoeken tot zwangerschapsafbreking na twaalf weken en hadden deze personen graag nog willen helpen.

De uitbreiding van de zwangerschapstermijn wordt door de tegenstanders van het wetsvoorstel bekritiseerd. Zo wordt in de eerste plaats aangehaald dat in kaart

71 Verslag van de Nationale Commissie voor de evaluatie van de wet van 3 april 1990 betreffende de zwangerschapsafbreking. Verslag ten behoeve van het parlement (hierna: Evaluatiecommissie Zwangerschapsafbreking): 1 januari 2012 - 31 december 2013, 2014, p. 16; verslag Evaluatiecommissie Zwangerschapsafbreking 1 januari 2014 - 31 december 2015, p. 16; verslag Evaluatiecommissie Zwangerschapsafbreking 1 januari 2016 - december 2017, 2018, p. 18.

72 Toelichting Parl.St. 2019, nr. 55-158/1, p. 4; S. Van de Velde e.a., 'Characteristics of Women Who Present for Abortion Beyond the Legal Limit in Flanders, Belgium', Perspectives on Sexual and Reproductive Health 2019 vol. 51, nr. 3, p. 175-183.

73 Toelichting Parl.St. 2019, nr. 55-158/1, p. 4. 
moet worden gebracht wat de achtergrond en motieven zijn van de personen die na twaalf weken de zwangerschap wensen af te breken. Op basis hiervan zou men moeten inzetten op preventie van ongewenste zwangerschappen, o.m. door het ter beschikking stellen van anticonceptiva. ${ }^{74}$ Uit de verslagen van de Nationale Commissie voor de Evaluatie van de Wet van 3 april 1990 betreffende de Zwangerschapsafbreking (hierna Evaluatiecommissie Zwangerschapsafbreking) blijkt dat er vanuit de praktijk inderdaad een nood bestaat aan preventieve maatregelen, zoals informatieverspreiding en voorlichting over, en beschikbaarheid van, anticonceptie en de noodpil. ${ }^{75}$ Dit wordt thans (deels) gerealiseerd, o.a. door de Wet van 22 april 2019 die voorziet in de tegemoetkoming in de kostprijs van anticonceptie voor vrouwen jonger dan 25 jaar (in plaats van 21 jaar) en in de kostprijs van de noodpil of 'morning-afterpil' voor alle vrouwen, ongeacht hun leeftijd. ${ }^{76}$ Deze maatregelen traden in werking op 1 april 2020. Uit het verslag van de Evaluatiecommissie Zwangerschapsafbreking blijkt verder ook dat dergelijke maatregelen moeten gepaard gaan met een versterking van de toegang tot vrijwillige zwangerschapsafbreking. ${ }^{77}$

Het valt niet te verwachten dat het uitbreiden van de termijn naar achttien weken ertoe zal leiden dat een grote groep zwangere personen zal besluiten tot een zwangerschapsafbreking na twaalf weken. Uit de cijfers in Nederland, waar een abortustermijn geldt van 24 weken, blijkt in ieder geval dat $82 \%$ van de zwangerschapsafbrekingen nog steeds plaatsvindt in het eerste trimester. ${ }^{78}$ Voor de overige $18 \%$ is het onduidelijk in hoeverre het gaat om zwangerschapsafbrekingen na prenatale diagnostiek en dus wegens foetale indicatie. ${ }^{79}$ Aangezien dit voor een deel zeker het geval zal zijn, blijft het aantal zwangerschapsafbrekingen zonder maternale of foetale indicatie ${ }^{80}$ in het tweede trimester eerder gering. Binnen de voormelde $82 \%$ vindt het grootste deel van de zwangerschapsafbrekingen in Nederland overigens plaats binnen de eerste zeven weken van de zwangerschap. ${ }^{81}$ Vergelijkbare cijfers zijn terug te vinden voor het Verenigd Koninkrijk, waar bijvoorbeeld in 2015 meer dan $90 \%$ van het aantal zwangerschapsafbrekingen plaatsvond in het eerste tri-

74 Zie bv. verslag Parl.St. 2019-20, nr. 55-0158/4, p. 13.

75 Zie bv. verslag Evaluatiecommissie Zwangerschapsafbreking 1 januari 2016 - 31 december 2017, 2018, p. 69.

76 Wet van 22 april 2019 tot wijziging van het koninklijk besluit van 16 september 2013 tot vaststelling van een specifieke tegemoetkoming in de kostprijs van contraceptiva voor vrouwen, jonger dan 21 jaar, teneinde terugbetalingsmogelijkheden voor contraceptiva en de morning-afterpil uit te breiden, BS 23 mei 2019.

77 Verslag Evaluatiecommissie Zwangerschapsafbreking 1 januari 2016 - 31 december 2017, 2018, p. 70; zie ook de toelichting bij het wetsontwerp tot wijziging van het koninklijk besluit van 16 september 2013 ter vaststelling van een specifieke tegemoetkoming in de kostprijs van contraceptiva voor vrouwen, jonger dan 21 jaar, teneinde de terugbetalingsmogelijkheden voor contraceptiva en de morning-afterpil uit te breiden, Parl.St. 2018-19, nr. 54-3439/1, p. 3.

78 Inspectie gezondheidszorg en jeugd, 'Jaarreportage Wet afbreking zwangerschap 2018', Utrecht 2019 (NL), p. 16, nr. 4.1.

79 Inspectie gezondheidszorg en jeugd Jaarreportage Wet afbreking zwangerschap 2017, Utrecht 2019 (NL), p. 20, nr. 5.4 .

80 Zie 3.2.2 Maternale en foetale indicatie.

81 Inspectie gezondheidszorg en jeugd, 'Jaarreportage Wet afbreking zwangerschap 2018', Utrecht 2019 (NL), p. 16, nr. 4.1. 
mester van de zwangerschap. ${ }^{82}$ Net zoals in Nederland is zwangerschapsafbreking op verzoek daar mogelijk tot 24 weken. Op basis van deze cijfers is het aannemelijk dat bij een termijnuitbreiding het aantal zwangerschapsafbrekingen na twaalf weken ook in België beperkt zal blijven.

\subsubsection{Van twaalf naar achttien weken}

De indieners van het wetsvoorstel hebben bij de keuze voor een termijn van achttien weken inspiratie gezocht in de zwangerschapstermijnen die gelden in andere Europese landen. Zo hanteert Zweden een zwangerschapstermijn van achttien weken. ${ }^{83}$ Hierbij moet worden opgemerkt dat in Zweden een zwangerschapstermijn geldt van achttien weken amenorroe. ${ }^{84}$ Dit betekent dat de zwangerschapstermijn wordt berekend vanaf de eerste dag van de laatste menstruatie (menstruele leeftijd). De bevruchting vindt gewoonlijk pas twee weken na dit ogenblik plaats, ${ }^{85}$ waardoor een termijn van achttien weken amenorroe neerkomt op zestien weken postconceptie (foetale leeftijd). Aangezien de termijn in het wetsvoorstel verwijst naar achttien weken postconceptie, is deze termijn twee weken langer dan deze die geldt in Zweden. De wetgever vermeldt verder ook Finland en Oostenrijk, ${ }^{86}$ waar een zwangerschapstermijn van veertien weken zou gelden. De wetgever lijkt echter ook hier geen rekening te hebben gehouden met het verschil tussen de menstruele en de foetale leeftijd. De zwangerschapstermijn in Finland bedraagt immers twaalf weken postconceptie en is dus gelijk aan de huidige zwangerschapstermijn in België. ${ }^{87}$

Zoals in het wetsvoorstel ook wordt aangehaald is een zwangerschapstermijn van achttien weken echter niet uitzonderlijk liberaal ten opzichte van andere Europese landen. Nederland, ${ }^{88}$ het Verenigd Koninkrijk ${ }^{89}$ (beide 24 weken) en IJsland ${ }^{90}$ (22

82 Zie voor concrete cijfers: British Medical Association, 'Decriminalisation of abortion: a discussion paper from the BMA', 2017, p. 19-20, www.bma.org.uk/media/1142/bma-paper-on-the-decriminalisationof-abortion-february-2017.pdf.

83 Toelichting bij wetsvoorstel, Parl.St. 2019-20, nr. 55-0158/1, p. 3; Abortlag (1974: 595), http:// rkrattsbaser.gov.se/sfst?bet=1974:595.

84 Zie bv. p. Fournet, 'Interruption volontaire de grossesse: le cadre juridique français', Journal de Gynécologie Obstétrique et Biologie de la Reproduction 2016, nr. 45, p. (1577) 1581 en ZonMw, 'Evaluatie Wet afbreking zwangerschap', Den Haag 2005, p. 53.

85 M. F. Schutte, D. De Mul, P.J.M. Van Kesteren en J. M. M. Van Lith, Verloskunde, gynaecologie, en kindergeneeskunde, Houten: Bohn Stafleu van Loghum 2009, p. 75.

86 Zie art. 97 Oostenrijks StGB op grond waarvan zwangerschapsafbreking op verzoek mogelijk is tot drie maanden na het begin van de zwangerschap. Men neemt echter aan dat de termijn van twaalf weken moet worden berekend vanaf de voltooide implantatie van het embryo wat dus neerkomt op veertien weken postconceptie; The law library of Congress, "Abortion legislation in Europe, januari 2015, 5; www.loc.gov/law/help/abortion-legislation/europe.php\#Finland.

$87 \S 5$, tweede lid Wet inzake de zwangerschapsafbreking van 24 maart 1970/239 www.womenonwaves. org/en/page/4773/abortion-law-finland.

88 Op basis van artikel 82a Sr. In de praktijk wordt echter aangeknoopt bij 22 weken aangezien artsen de zwangerschapsduur slechts tot op twee weken nauwkeurig zouden kunnen bepalen; Memorie van toelichting bij regelen tot het afbreken van zwangerschap, Kamerstukken II, 15-475, nr. 3, 32-33.

89 Art. 1 eerste lid (a) Abortion act 1967.

90 Artikel 4 van de Wet op Abortus (Lög um pungunarrof), 22 mei 2019, nr. 2019/43. 
weken) voorzien immers in een langere zwangerschapstermijn.${ }^{91}$ Hierbij gelden zowel in Nederland ${ }^{92}$ als in het Verenigd Koninkrijk ${ }^{93}$ ook vóór deze termijn inhoudelijke voorwaarden om tot vrijwillige zwangerschapsafbreking over te gaan. Deze voorwaarden worden echter dermate ruim geïnterpreteerd dat zwangerschapsafbreking vóór het verstrijken van deze termijn steeds mogelijk zal zijn op verzoek van de zwangere persoon. ${ }^{94}$

Door tegenstanders van het wetsvoorstel wordt aangehaald dat de keuze voor een termijn van achttien weken onvoldoende wordt onderbouwd.$^{95}$ In het licht van de continue ontwikkeling van de foetus kan de achttienwekentermijn o.i. inderdaad worden beschouwd als eerder willekeurig. Een zekere willekeur kan echter worden teruggevonden bij iedere andere termijn binnen de periode vanaf de verwekking tot aan de geboorte. Zo wordt in de toelichting bij de Wet zwangerschapsafbreking van 1990 reeds toegegeven dat op de keuze van een termijn van twaalf weken kritiek kan worden geuit. ${ }^{96}$ Niettemin werden ter onderbouwing van deze termijn de volgende overwegingen aangehaald. De termijn zou ten eerste overeenkomen met de overgang van de embryonale periode naar de foetale periode. ${ }^{97}$ Hier valt echter wel wat op aan te merken. Dit komt immers niet overeen met de invulling die gewoonlijk aan de begrippen embryo en foetus wordt gegeven, waarbij de overgang tussen beide doorgaans op acht weken wordt geplaatst (art. 2, $4^{\circ}$ en $5^{\circ}$ Wet menselijk lichaamsmateriaal). Dit kwam ook in de voorbereidende werken van het toenmalige wetsvoorstel tot uiting. ${ }^{98}$ De wetgever was hier dus niet consistent. Daarnaast blijft de overgang van embryo naar foetus een eerder willekeurig gekozen ogenblik in de ontwikkeling van ongeboren leven. Er is immers geen vanzelfsprekende reden op grond waarvan aan 'het embryo' steeds minder bescherming dient toe te komen dan aan 'de foetus'.

Een tweede reden om de grens in 1990 vast te leggen op twaalf weken bestond erin dat volgens de toenmalige stand van de wetenschap het op twaalf weken zwanger-

91 De berekening van de zwangerschapstermijn gebeurt in de drie voormelde landen gewoonlijk vanaf de eerste dag van de laatste menstruatie (amenorroe). Dit kan echter niet uit de toepasselijke wetgeving zelf worden afgeleid.

92 In Nederland is vereist dat de zwangere persoon zich in een noodsituatie bevindt (art. 5 Wet afbreking zwangerschap).

93 In het Verenigd Koninkrijk is vereist dat de voortzetting van de zwangerschap een groter risico inhoudt dan de beëindiging ervan of dat de voortzetting van de zwangerschap schade aan de fysieke of mentale gezondheid veroorzaakt van de zwangere persoon, reeds geboren kinderen of andere familieleden (art. 1, eerste lid (a) Abortion act 1967).

94 Memorie van toelichting bij regelen tot het afbreken van zwangerschap, Kamerstukken II, 15-475, nr. 3, 9 en memorie van antwoord bij regelen tot het afbreken van zwangerschap, Kamerstukken I, 15-475, nr.59b, 15 (Nederland); G. T. Laurie, S. H. E. Harmon en E. S. Dove, Mason \& McCall Smith's law \& medical ethics Oxford: Oxford University Press,2019, p. 312 (Verenigd Koninkrijk); F. De Meyer, 'Late Termination of Pregnancy in Belgium: Exploring Its Legality and Scope', European Journal of Health Law 2020 vol. 27, nr. 1, p. 25 en p. 26 (voetnoot 65).

95 Zo wordt aangehaald dat voor de keuze van een termijn van achttien weken geen 'objectieve argumenten’ beschikbaar zijn; Amendement nr. 17 Parl.St. Kamer, nr. 55-0158/11, p. 2.

96 Memorie van toelichting Parl.St. Senaat BZ 1988, nr. 247-1, p. 11.

97 Verslag Parl.St. Senaat BZ 1988, nr. 247-2, p. 29.

98 Verslag Parl.St. Senaat BZ 1988, nr. 247-2, p. 28. 
schap mogelijk werd om vast te stellen of het kind na de geboorte zou lijden aan een (zware) afwijking. ${ }^{99}$ Ook dit argument is niet sluitend. De ontdekking van een ernstige kwaal na twaalf weken zou immers nog steeds aanleiding kunnen geven tot een zwangerschapsafbreking, gelet op de uitzondering voorzien bij foetale indicatie (art. 2, $5^{\circ}$ Wet Vrijwillige Zwangerschapsafbreking). Vandaag kunnen bepaalde chromosomale aandoeningen aan de hand van de NIP-test ${ }^{100}$ bovendien reeds op een vroeger tijdstip aan het licht komen, met name rond de negen à tien weken postconceptie. Andere aandoeningen kunnen daarentegen pas op een later tijdstip in de zwangerschap met redelijke zekerheid worden vastgesteld.

De termijn van twaalf weken in 1990 moet in het licht van het voorgaande vooral worden gezien als een compromis tussen de verschillende partijen dat de toenmalige tijdsgeest en opvattingen over vrijwillige zwangerschapsafbreking reflecteerde. ${ }^{101}$ De twaalfwekentermijn weerspiegelt hierbij de trimesteropdeling, aan de hand waarvan zwangerschappen in de medische praktijk vaak worden opgedeeld. ${ }^{102}$ Maar ook de overgang van het eerste naar het tweede trimester van de zwangerschap biedt geen duidelijk normatief ankerpunt op grond waarvan de bescherming van de foetus automatisch groter dient te worden.

Wetgevers worstelen terecht met het onderbouwen van de keuze voor een welbepaalde zwangerschapstermijn. De keuze van een termijn moet o.i. echter worden beschouwd als een beleidskeuze, waarvoor nooit een sluitende argumentatie kan worden gevonden. ${ }^{103}$ Afhankelijk van de prioriteiten van de wetgever zal voor een strenge, dan wel voor een liberale termijn worden gekozen. In het licht van de doelstelling van het huidige wetsvoorstel, namelijk het versterken van het zelfbeschikkingsrecht van de zwangere persoon en het beperken van abortustoerisme, kan een uitbreiding van de termijn in ieder geval wel worden verantwoord.

De uitbreiding naar achttien weken zou volgens de oppositie ook een aantal bijzondere nadelen met zich meebrengen. In het bijzonder de mogelijkheid voor potentiele ouders om aan geslachtsselectie te doen, baart verschillende parlementsleden zorgen. Ondanks het zeer geringe bewijs voor geslachtsselectieve abortus in België, is dit een terugkerend argument in het betoog van tegenstanders van een ter-

99 Verslag Parl.St. Senaat BZ 1988, nr. 247-2, p. 118.

100 De niet-invasieve prenatale test waarmee bepaalde chromosoomafwijkingen zoals het syndroom van down kunnen worden opgespoord.

101 De termijn van twaalf weken kan ook worden teruggevonden in Duitsland ( $\$ 218$ a, eerste lid 3. StGB). In Frankrijk werd de termijn in 2001 opgetrokken van tien naar twaalf weken (art. L2212-1 Code de la santé publique).

102 De trimesteropdeling komt ook sterk tot uiting in de Amerikaanse abortusrechtspraak: Roe v. Wade 1973, 410 U.S. 113 (1972).

103 S. A. M. Mclean, Autonomy, consent and the law, Oxon: Routledge Cavendish 2010, p. 129. 
mijnuitbreiding. ${ }^{104}$ Hoewel het vermijden van abortus op basis van geslacht een legitieme doelstelling kan vormen, ${ }^{105}$ volstaat dit o.i. niet als doorslaggevend argument tegen een termijnuitbreiding van twaalf naar achttien weken. Ten eerste was het onder de Wet Zwangerschapsafbreking 1990 reeds mogelijk om naar aanleiding van de NIP-test het geslacht van de foetus te kennen vóór de huidige termijn van twaalf weken en zes dagen (dit komt overeen met veertien weken en zes dagen amenorroe) en op basis daarvan de zwangerschapsafbreking te vragen. De vraag om bijkomende bescherming voor (doorgaans) vrouwelijke foetussen had dus reeds opgeworpen kunnen worden toen de wetgever in 2018 wijzigingen doorvoerde aan de wet. ${ }^{106}$ Belangrijker is echter de duidelijke en gedragen intentie van alle partijen om geen inhoudelijke voorwaarden te stellen aan de reden voor vrijwillige zwangerschapsafbreking vóór twaalf weken, wanneer zij in 2018 de vereiste van de 'noodsituatie' schrapten. De wetgever heeft hier dus bewust geen ruimte gelaten voor een normatieve beoordeling van de door de zwangere persoon ingeroepen reden. ${ }^{107}$ Ten slotte kan elke gezondheidszorgbeoefenaar zich nog steeds beroepen op het wettelijk verankerd weigeringsrecht om mee te werken aan de zwangerschapsafbreking die zou zijn ingegeven door een voorkeur voor het geslacht. Mocht in de toekomst alsnog een maatschappelijk probleem inzake geslachtsselectieve abortussen van vrouwelijke foetussen ontstaan, dan is het volgens ons aan de wetgever om maximaal in te zetten op preventie, bewustmaking en maatregelen die de positie van meisjes en vrouwen in de samenleving versterken.

Om zich te kunnen wapenen tegen mogelijke geslachtsselectieve abortussen dienden tegenstanders van het wetsvoorstel verschillende amendementen in. Een eerste amendement verbiedt abortus omwille van het geslacht van het ongeboren kind zonder dat daar een medische reden voor is. ${ }^{108}$ In een later amendement wordt ook voorzien in een strafsanctie bij overtreding van dit verbod. ${ }^{109}$ Een ander amendement, dat nadien werd ingetrokken, ${ }^{110}$ hield een verbod in om het geslacht dat

104 De Evaluatiecommissie Zwangerschapsafbreking maakt in haar tweejaarlijks verslag van 2018 melding van twee verzoeken op basis van het geslacht van het embryo in de abortuscentra. Één ziekenhuis meldt dat zij te maken krijgen met aanvragen op basis van het geslacht, maar geeft de frequentie ervan niet aan. Zowel in de centra als in het ziekenhuis werden dergelijke verzoeken geweigerd; verslag Evaluatiecommissie Zwangerschapsafbreking 1 januari 2014 - 31 december 2015, 2016, p. 16; verslag Evaluatiecommissie Zwangerschapsafbreking 1 januari 2016 - december 2017, 2018, p. 81.

105 Zie het advies RvS van 19 juni 2020 nr. 67.122/AV, Parl.St. Kamer 2019-20, nr. 55-0158/12, p. 14.

106 Ook onder de termijn van twaalf weken zonder wachtperiode vóór 2018 was abortus op basis van geslachtsselectie overigens reeds mogelijk. Het geslacht kan immers worden meegedeeld samen met de resultaten van de NIP-test, welke gewoonlijk wordt gedaan op 10 weken postconceptie. De resultaten hiervan zijn in beginsel beschikbaar vier werkdagen volgend op de test, waardoor de wachttermijn nog kan worden gerespecteerd binnen de twaalf-weken grens.

107 Zie ook G. T. Laurie, S. H. E. Harmon en E. S. Dove 2019, p. 314 waarin niet wordt uitgesloten dat een abortus op basis van geslachtsselectie ook kan worden verantwoord in het licht van de (mentale) gezondheid en het welzijn van de zwangere persoon.

108 Amendement nr. 42 Parl.St. Kamer 2019-20, nr. 55-0158/11, p. 48.

109 Amendement nr. 55 Parl.St. Kamer 2019-20, nr. 55-0158/13, p. 9.

110 Door Amendement nr. 55 Parl.St. Kamer 2019-20, nr. 55-0158/13, p. 9. Het amendement werd door de indienster ervan ingetrokken aangezien het niet de bedoeling was geweest met het amendement "andere vrouwen/paren te bestraffen die het geslacht van hun ongeboren kind wensen te kennen vóór de achttiende week na de bevruchting”. 
blijkt uit de prenatale test mee te delen vóór de twintigste week amenorroe ${ }^{111}$ (de uiterste datum waarop een vrijwillige zwangerschapsafbreking op verzoek mag plaatsvinden, tenzij er een medische reden voor bestaat). ${ }^{112}$ De Raad van State oordeelde in zijn tweede advies dat deze amendementen een legitieme doelstelling nastreven en proportioneel zijn in het licht van die doelstelling. De Raad van State verwijst hierbij ook naar de wetgeving inzake pre-implantatiediagnostiek (PID), waarbij PID gevolgd door embryoselectie op basis van geslacht uitdrukkelijk wordt verboden en strafbaar gesteld. ${ }^{113}$

De vergelijking met embryoselectie na PID gaat hier echter niet volledig op, aangezien het embryo op dit ogenblik nog niet is verbonden met het lichaam van de zwangere persoon. Deze verbondenheid vormt, in het kader van de abortuswetgeving, echter de voornaamste overweging bij de bescherming van het zelfbeschikkingsrecht van de zwangere persoon. De fysieke en psychische integriteit van deze laatste wordt immers aanzienlijk aangetast bij de verplichting om de zwangerschap uit te dragen. Dit zelfbeschikkingsrecht kan uiteraard wel worden beperkt, onder meer ter bescherming van het ongeboren leven maar ook in het licht van het voorkomen van eugenetische praktijken. Zoals vermeld, heeft de wetgever in 2018 door het schrappen van de noodsituatie echter gekozen om voorrang te geven aan de bescherming van het zelfbeschikkingsrecht van de zwangere persoon binnen een bepaalde zwangerschapstermijn. Hoewel een verbod op abortus wegens geslachtsselectie dus een legitieme beleidskeuze kan vormen, is dit verbod inconsistent in het licht van de eerder gemaakte keuze van de wetgever. In ieder geval zal een dergelijk verbod leiden tot een verstrenging van de huidige abortuswetgeving en zo een verdere inperking inhouden van het zelfbeschikkingsrecht van de zwangere persoon. Bovendien doet ook de beperkte mate van afdwingbaarheid van een verbod op geslachtsselectie enige twijfel zaaien over het nut en de proportionaliteit van een dergelijke maatregel.

De termijn van achttien weken zou zich ten slotte ook te dicht bij de zogenaamde levensvatbaarheidsgrens bevinden. Wat onder het begrip levensvatbaarheidsgrens moet worden verstaan, is onduidelijk. In het kader van abortuswetgeving wordt hierbij meestal aangeknoopt bij een zwangerschapstermijn van 24 weken. ${ }^{114}$ De wettelijke levensvatbaarheidsgrens die wordt afgeleid uit artikel 326 BW ligt daarentegen op 180 dagen of 26 weken postconceptie. Aangezien volgens de Wereldgezondheidsorganisatie pas ten vroegste sprake kan zijn van levensvatbaarheid bij

111 De Raad van State merkte in haar tweede advies terecht op dat het amendement zich - in het licht van de rechtszekerheid - beter bedient van de post-conceptionele achttienwekentermijn: advies RvS van 19 juni 2020 nr. 67.122/AV, Parl.St. Kamer 2019-20, nr. 55-0158/12, p. 21-22.

112 Amendement nr. 43 Parl.St. Kamer 2019-20, nr. 55-0158/11, p. 50. De medische redenen waarvan sprake worden niet toegelicht, al kan worden afgeleid uit de verantwoording bij het amendement dat dit wordt geïnterpreteerd naar analogie van de geslachtsgebonden ziekten waarvan sprake in de wet van 11 mei 2003 betreffende het onderzoek op embryo's in vitro en de MBV-wet.

113 Zie artikels 67, $2^{\circ}$ en $73 \mathrm{MBV}$-wet. Enkel geslachtsselectie ter voorkoming van geslachtsgebonden ziekten is toegelaten.

114 Zie bv. Verslag Parl.St. Senaat BZ 1988, nr. 247-2, p. 148. 
twintig weken postconceptie, ${ }^{115}$ moet in ieder geval worden aangenomen dat de grens van achttien weken nog ruim voor de levensvatbaarheid kan worden gesitueerd.

\subsubsection{Implementatie in de praktijk en abortusmethode}

Wat betreft de praktische implicaties van een termijnverlenging wordt vooral de gebruikte abortusmethode na twaalf weken zwangerschap aangehaald. De abortusmethode die gebruikelijk is op twaalf weken en daarvoor kan immers niet worden gehanteerd op achttien weken. ${ }^{116}$ Een afbreking op achttien weken zou een fysiek en psychisch ingrijpendere 'minibevalling' of verwijdering met instrumenten vereisen. Het klopt dat de gebruikte abortusmethode afhankelijk is van de zwangerschapstermijn. In de vroege zwangerschap ${ }^{117}$ kan de zwangerschap worden beëindigd met de abortuspil. ${ }^{118}$ Dit vormt de minst ingrijpende methode en leidt vóór twaalf weken bijna nooit tot complicaties. ${ }^{119}$ Verder kan gebruik worden gemaakt van een curettage of vacuümaspiratie. ${ }^{120}$ Bij beide methoden is de kans op complicaties in een vroeg stadium van de zwangerschap eveneens zeer gering. ${ }^{121}$ $\mathrm{Na}$ twaalf weken vindt de zwangerschapsafbreking in België gewoonlijk plaats door de bevalling medicinaal in te leiden. De zwangerschapsafbreking kan daarnaast ook instrumenteel gebeuren door dilatatie en evacuatie. ${ }^{122}$ Over de mogelijke complicaties bij deze ingreep zijn in de verslagen van de Evaluatiecommissie Zwangerschapsafbreking geen gegevens opgenomen, nu deze niet courant wordt gebruikt in België. Uit buitenlandse bronnen blijkt voor beide methoden niettemin dat de kans op complicaties ook bij zwangerschapsafbreking in het tweede trimester gering blijft, maar wel groter wordt naarmate de zwangerschap vordert. ${ }^{123}$

115 http://www.who.int/maternal_child_adolescent/topics/maternal/maternal_perinatal/en/; F. Swennen, 'Dance me to the children who are asking to be born'. Over levenloos geborenen en ongeborenen', TPR 2016, afl. 2-3, p. (407) 412; A. Huygens, 'Late zwangerschapsafbrekingen en aansprakelijkheid voor ongewenst bestaan', T. Gez. 2011-2012, afl. 3, p. (212) 215. H. Nys, 'De nieuwe wetgeving inzake zwangerschapsafbreking', RW 1991, nr. 35, p. (1189) 1189.

116 Toelichting bij amendement nr. 17 Parl.St. 2019-20, nr. 55-0158/11, p. 2.

117 Gewoonlijk tot zeven weken postconceptie.

118 De term abortuspil is hierbij misleidend, aangezien het doorgaans om verschillende pillen gaat die een miskraam veroorzaken. Voor zeven weken blijkt deze methode effectiever dan aspiratie. M. Berer, 'Medical Abortion: Issues of Choice and Acceptability', Reproductive Health Matters 2005 vol. 13, nr. 26, p. 27.

119 Verslag Evaluatiecommissie Zwangerschapsafbreking 1 januari 2012 - 31 december 2013, 2014 p. 38; verslag Evaluatiecommissie Zwangerschapsafbreking 1 januari 2014 - 31 december 2015, 2016, p. 38; verslag Evaluatiecommissie Zwangerschapsafbreking 1 januari 2016 - 31 december 2017, 2018, p. 40.

120 Deze methode wordt in België het vaakst gebruikt: zie bv. verslag Evaluatiecommissie Zwangerschapsafbreking 1 januari 2016 - 31 december 2017, 2018, p. 27. Vacuümaspiratie omvat het gebruik van een dunne buis waardoor het weefsel voorzichtig uit de baarmoeder wordt gezogen.

121 Verslag Evaluatiecommissie Zwangerschapsafbreking 1 januari 2012 - 31 december 2013, 2014, p. 39.

122 Zie hierover voor Nederland: Nederlands Genootschap van Abortusartsen (NGvA), 'Richtlijn behandeling van vrouwen die een zwangerschapsafbreking ondergaan', 2015, p. 118 e.v, beschikbaar op: https://www.ngva.net/professionele-standaarden.

123 Zie o.a. Nederlands Genootschap van Abortusartsen (NGvA) 2015, p. 5-6, 118-122; Royal College of Obstetricians and Gyneacologists, 'The care of women requesting induced abortion (evidence-based clinical guideline nr. 7)', 2011, p. 39-40. 
Een verhoging van de zwangerschapstermijn van twaalf naar achttien weken zou vervolgens ook problemen opleveren aangezien de abortuscentra niet voorbereid zijn op het verrichten van zwangerschapsafbrekingen na twaalf weken. Hoewel de gevolgen van een wetswijziging op de praktijk een terechte overweging vormen, is een mogelijk gebrek aan voorbereiding evident aangezien abortuscentra gedurende drie decennia louter het mandaat hadden om afbrekingen vóór twaalf weken uit te voeren. Niets weerhoudt de medische professie of de wetgever er echter van om actief de nodige reorganisatie te bewerkstelligen. Het wetsvoorstel had bijvoorbeeld kunnen voorzien in een systeem gelijkaardig aan dat in Nederland. Hier gelden vanaf een zwangerschapsduur van dertien weken enkel bijkomende procedurele voorwaarden, welke betrekking hebben op de plaats waar de zwangerschapsafbreking kan worden uitgevoerd en de diensten die hierbij aanwezig moeten zijn. ${ }^{124}$ De praktische bezwaren die bestaan in verband met zwangerschapsafbreking na twaalf weken zouden op deze manier kunnen worden opgelost. ${ }^{125}$ De tegenstanders van het wetsvoorstel putten dan ook inspiratie uit het Nederlandse voorbeeld bij het formuleren van twee amendementen die aan de problematiek tegemoet komen. ${ }^{126}$ Een eerste amendement tracht de zwangerschapsafbrekingen na twaalf weken tot de exclusieve bevoegdheid te maken van ziekenhuizen zoals omschreven in artikel 2 van de Gecoördineerde wet op de ziekenhuizen en andere verzorgingsinrichtingen. Een gelijkaardig amendement behoudt zwangerschapsafbrekingen na twaalf weken voor aan erkende instellingen voor gezondheidszorg. Een diepgaander overleg met de medische sector over deze of andere maatregelen met oog op de praktische reorganisatie van abortusvoorziening had o.i. aangewezen geweest.

Bij de keuze voor een zwangerschapstermijn in abortuswetgeving moet o.i. steeds een onderscheid worden gemaakt tussen procedurele of pragmatische zwangerschapstermijnen enerzijds en substantiële zwangerschapstermijnen anderzijds. De eerste zijn hierbij hoofdzakelijk ingegeven door de medische en praktische risico's die een late(re) zwangerschapsafbreking mogelijk met zich meebrengt en waarbij na het verstrijken van deze termijn enkel bijkomende procedurele voorwaarden gelden. Een voorbeeld hiervan is de voormelde termijn van dertien weken in $\mathrm{Ne}$ derland. Bij het opleggen van een substantiële zwangerschapstermijn wordt door de wetgever daarentegen een normatief standpunt ingenomen over de toelaatbaarheid van zwangerschapsafbreking, gelet op de verder gevorderde zwangerschap en in het verlengde hiervan de verder gevorderde ontwikkeling van de foetus. $\mathrm{Na}$ het verstrijken van deze termijn is zwangerschapsafbreking niet meer, of slechts onder strengere inhoudelijke voorwaarden, toegelaten. De hier voorgestelde termijn van achttien weken moet worden beschouwd als een substantiële zwangerschapstermijn. De wetgever voorziet immers in strengere inhoudelijke voorwaarden na achttien weken. Vanaf dit ogenblik wordt de voorkeur gegeven aan de

124 Zie art. 21- 24 Nederlandse Wet afbreking zwangerschap en ZonMw, 'Tweede evaluatie Wet afbreking zwangerschap', Den Haag 2020, p. 51.

125 De Koning kan steeds nadere regels bepalen inzake de structuur en organisatie van gezondheidszorg ter garantie van de hoogstaande kwaliteit ervan op basis van artikel 32 van de Kwaliteitswet.

126 Amendementen nr. 18 en nr. 41 Parl.St. Kamer 2019-20, nr. 55-0158/11, p. 4; p. 46-47. 
bescherming van ongeboren leven boven het zelfbeschikkingsrecht van de zwangere persoon, behoudens in uitzonderlijke gevallen. De keuze voor een dergelijke termijn houdt dus vooral een ethische beleidskeuze in. Hoewel de gebruikte methode en de daarmee geassocieerde risico's mogelijk wel een rol kunnen spelen in het onderbouwen van een termijn, moeten deze overwegingen worden afgewogen tegen beleidsethische overwegingen die de keuze voor een bepaalde termijn motiveren.

\subsection{Procedurele en inhoudelijke voorwaarden}

\subsubsection{De wachtperiode}

Artikel 2 van het wetsvoorstel brengt tevens een verkorting van de verplichte wachtperiode ${ }^{127}$ tot stand, welke thans zes dagen tussen de eerste raadpleging met een arts en het verrichten van de ingreep bedraagt. ${ }^{128}$ De wachtperiode zou tot doel hebben om ervoor te zorgen dat de zwangere persoon met voldoende kennis van zaken de beslissing tot zwangerschapsafbreking kan nemen. ${ }^{129}$ Tijdens deze periode kan de zwangere persoon ook hulp zoeken om de zwangerschap uit te dragen. ${ }^{130}$ Hoewel de wachtperiode voornamelijk zou zijn ingegeven met het oog op de bescherming van de zwangere persoon, blijkt ze daarnaast ook deels ingegeven met het oog op de bescherming van het ongeboren leven. Dit kan o.m. worden afgeleid uit de voorbereidende werken bij de Wet zwangerschapsafbreking van 1990. In de toelichting van een amendement bij deze wet werd aangehaald dat 'abortus een ernstige ingreep is, aangezien een menselijk leven wordt vernietigd en de wetgever er dan ook voor moet zorgen dat het aantal beperkt blijft en dat de wetgeving objectief gesproken een afschrikwekkende werking heeft. Daarom worden er twee eisen gesteld, nl. de opvang van de vrouw en de bedenktijd'. ${ }^{131}$ Hoewel dit amendement werd verworpen verschillen de bepalingen vooropgesteld in dit amendement inhoudelijk niet van de voorwaarden opgenomen in oud artikel 350 Sw., welke vervolgens werden overgenomen in de Wet Vrijwillige Zwangerschapsafbreking. Vandaag wordt de wachtperiode door velen echter beschouwd als een paternalistische en voorbijgestreefde belasting van de zwangere persoon. ${ }^{132}$ Deze kritiek werd reeds geuit bij de totstandkoming van de Wet Vrijwillige Zwangerschapsafbreking in

127 Vaak gebruikte synoniemen voor deze term zijn de wachttijd, de wachttermijn, de reflectieperiode, de beraadtermijn, alsook het meer suggestieve 'bedenktijd'.

128 Artikel 2, $3^{\circ}$ Wet Vrijwillige Zwangerschapsafbreking. Er heerst enige verwarring over het aanvangspunt van de wachtperiode en het karakter van het eerste consult, zie o.m. Vansweevelt 2014, p. 251-252; Rb. Brugge 7 februari 2007, T.Gez/Rev.dr.santé 2006-07, 186, noot M.-N. Veys; H. NYS 2005, nr. 536; W. Dijkhoffz, Christelijke mutualiteiten en socialistische mutualiteiten, Je rechten als patiënt, Berchem, EPO, 2008, 122; S. Callens en J. Peers (eds.), Organisatie van de gezondheidszorg, Antwerpen, Intersentia, 2008, 581, noot (2077); Interview Lucie Van Crombrugge, De Standaard, 22 augustus 2009, https://www.standaard.be/cnt/872e0r2v.

129 T. Vansweevelt, F. De Meyer en K. Van Assche 2018, p. 226; Toelichting, Parl.St. Senaat BZ 1988, 47-247/1, p. 11.

130 Parl.St. Kamer 2019-20, nr. 55-0158/1, p. 4.

131 Het amendement van Cerexhe, Falise e.a., Parl.St. Senaat BZ 1988, 47-247/5, p. 5.

132 Verantwoording bij amendement nr. 254-, Parl.St. Kamer 2019-20, nr. 55-0158/3, p. 7-8. 
2018, die uiteindelijk voorzag in een beperkte versoepeling van de wachtperiode. ${ }^{133}$ Van de zesdaagse wachtperiode kan sinds de Wet van 2018 worden afgeweken indien er voor de zwangere persoon een dringende medische reden bestaat om de zwangerschapsafbreking te bespoedigen. Wanneer het toepassen van de wachtperiode van zes dagen ervoor zou zorgen dat de twaalfwekentermijn wordt overgeschreden, wordt bovendien het aantal niet-verstreken dagen van de wachttijd bij de twaalfwekentermijn opgeteld. ${ }^{134}$

Het huidige wetsvoorstel wil verder gaan dan de Wet uit 2018 door de wachtperiode in te korten van zes dagen tot 48 uur. Net zoals werd ingevoerd met de wetswijziging van 2018 blijft een verlengingsmechanisme van toepassing wanneer de eerste raadpleging plaatsvindt op minder dan 48 uur voor het einde van de voorgestelde achttienwekentermijn. ${ }^{135}$ Vanuit de praktijk rees de vraag om een kortere wachtperiode, aangezien de meeste personen die om een zwangerschapsafbreking verzoeken - een expert sprak tijdens de parlementaire hoorzittingen over $95 \%-{ }^{136}$ bij het eerste consult al een beslissing hebben genomen en deze grondig hebben overdacht nadat zij kennis kregen van de zwangerschap. ${ }^{137}$ De verplichte wachttermijn van zes dagen zou dan ook overbodig zijn en zelfs problematisch voor zwangere personen die hun beslissing reeds lange tijd voordien hebben genomen. ${ }^{138}$ Bovendien zou niets de arts of zwangere persoon ervan weerhouden om alsnog een langere wachtperiode in acht te nemen.

De tegenstanders van het wetsvoorstel bekritiseerden de inkorting van de wachttermijn om uiteenlopende redenen. ${ }^{139}$ Vooreerst zou een kortere termijn de zwangere persoon niet voldoende beschermen tegen familiedruk en in die zin onmogelijk de vrije keuze van de zwangere persoon waarborgen. Verder biedt de wachttijd van zes dagen volgens hen een bescherming voor zwangere personen die twijfelen en uit paniek handelen, zodat zij nog van mening kunnen veranderen. Ook zou een verkorte wachtperiode volgens tegenstanders kunnen resulteren in een moeilijker verwerkingsproces. Ten slotte zou de keuze voor een 48-uren wachttermijn arbitrair zijn.

Over zin of onzin van een verplichte wachtperiode bestaat discussie. ${ }^{140}$ De Wereldgezondheidsorganisatie stelt alvast dat een verplichtte wachttijd een drempel vormt die de toegang tot een veilige en tijdige abortus kan belemmeren. ${ }^{141}$ Of de

133 Zie bijvoorbeeld Wetsvoorstel ertoe strekkende de vrijwillige zwangerschapsafbreking uit het Strafwetboek te lichten, Parl. St. Kamer 2018-19, nr. 54-3215/1, p. 5.

134 Art. 2, $3^{\circ}$ Wet Vrijwillige Zwangerschapsafbreking.

135 In dat geval wordt de niet-verstreken tijd van die 48u bij de 18-wekentermijn geteld.

136 Parl.St. Kamer 2019-20, nr. 55-0740/1, p. 6.

137 Verantwoording bij amendement nr. 2 Parl.St. Kamer 2019-20, nr. 55-0158/3, p. 7-8.

138 Zie bv. Parl.St. Kamer 2019-20, nr. 55-0740/1, p. 6.

139 Zie bv. Parl.St. 2019-20, nr. 55-0158/4, p. 39-40, p. 43.

140 Guttmacher Institute, 'The Impact of State Mandatory Counseling and Waiting Period Laws on Abortion: A Literature Review', New York, 2009.

141 WHO, 'Safe abortion: technical and policy guidance for health systems', Genève, 2012, 96. Zie ook de aanbeveling op p. 9: "Regulatory, policy and programmatic barriers that hinder access to and timely provision of safe abortion care should be removed." 
zwangere persoon gebaat is bij een wachtperiode is o.i. sterk afhankelijk van diens persoonlijke situatie. Uit de recente evaluatie van de Nederlandse abortuswet- en praktijk - waar een gelijkaardige 'beraadtermijn' van vijf dagen geldt - blijken juristen en zorgverleners voorstander van een flexibelere wachtperiode. ${ }^{142}$ Naast het identificeren van problemen met de implementatie van de beraadtermijn, gaf een groot deel van de bevraagde zorgverleners aan dat de wachtperiode te rigide is en door vrouwen als belastend wordt ervaren. ${ }^{143}$ Hoewel de betrokken zorgverleners tegelijk aangeven positief te staan tegenover het principe van een beraadperiode, struikelen zij over de strakke, bij wet gestipuleerde duur van de termijn. ${ }^{144}$ Ook tijdens de Belgische parlementaire debatten in 2018 riep een meerderheid van de opgeroepen experten op om de wachtperiode in te korten of zelfs af te schaffen. ${ }^{145}$ Naast een verwijzing naar gelijkaardige argumenten als bovenstaande, werd onder meer benadrukt dat het Belgisch zesdagencriterium internationaal en binnen Europa uitzonderlijk lang is. ${ }^{146}$

De inkorting van de wachtperiode geeft o.i. blijk van een groot vertrouwen in de arts en de voorlichtingsdienst om een langere termijn toe te passen mocht blijken dat de zwangere persoon uit druk of in paniek handelt. Toch kan men zich afvragen of het behoud van een wachtperiode - zelfs verkort - gerechtvaardigd en noodzakelijk is. Ook zonder verplichte wachttijd zal de arts immers gehouden zijn om de geïnformeerde toestemming van de zwangere persoon te verkrijgen en zich te vergewissen van haar vaste wil vooraleer hij de zwangerschapsafbreking uitvoert. ${ }^{147}$ Een zorgvuldig arts die deze plichten naleeft zal ongeacht de wettelijke wachtperiode een gepaste ondersteuning moeten bieden aan personen die twijfelen, in paniek handelen of onder druk staan. Ook kent de wachtperiode in de praktijk een soms moeilijke uitwerking. Hoewel de voorstanders van de zesdagenperiode benadrukken dat deze vooral waarborgen biedt in geval van zwangerschapsafbrekingen op foetale of maternale indicatie, blijkt de verplichte wachtperiode hier doorgaans overbodig. ${ }^{148}$ Meestal zal het traject van prenatale diagnostiek, wachten op uitslagen en overleg met verschillende zorgverleners de wachtperiode immers overschrijden. Uit de Nederlandse praktijk blijkt alvast dat artsen betrokken bij dergelijke 'medische zwangerschapsafbrekingen' de wachtperiode op een ander tijdstip laten ingaan, wat mogelijk in strijd is met de letter van de wet. ${ }^{149}$ De totale afschaf-

142 ZonMw, 'Tweede evaluatie Wet afbreking zwangerschap', Den Haag 2020, p. 83-86.

143 Ibid., p. 86.

144 Ibid., p. 105

145 Bijlage bij Verslag van de eerste lezing namens de commissie voor de justitie, Hoorzittingen, Parl. St. Kamer 2018-19, nr. 54-3216/3, p. 50, p. 54, p. 75, p. 76, p. 81, p. 86, p. 132.

146 Ibid, p. 50. De meeste Europese landen hebben geen bij wet verankerde wachtperiode (bv. Verenigd Koninkrijk, Frankrijk, Servië, Oostenrijk, Denemarken, Finland, Noorwegen, Ijsland, Zweden, Zwitserland, etc.). In de Europese landen die een wachtperiode hanteren bedraagt de duur ervan doorgaans drie dagen (bv. Duitsland, Ierland, Letland, Luxemburg, Hongarije, Polen, Portugal, Spanje, Montenegro, etc.). Slechts twee Europese landen, Italië en Albanië, hebben een wachtperiode die langer is dan de Belgische zes-dagen-periode, in casu zeven dagen.

147 Dit vloeit voort uit artikel 8 van de Wet Patiëntenrechten en artikel 2, 2 , c Wet Vrijwillige Zwangerschapsafbreking.

148 Verantwoording bij amendement nr. 21 Parl.St. Kamer 2019-20, nr. 55-0158/11, p. 9.

149 ZonMw 2020, p. 84. 
fing van de wachtperiode zou in elk geval geen afbreuk doen aan het feit dat medische interventies geagendeerd worden naargelang de urgentie, de medische capaciteit, de logistiek en de noden van de patiënt. Het ontbreken van een verplichte wachtperiode betekent geenszins dat het medisch personeel gedwongen zal zijn om onmiddellijk in de abortusprocedure te voorzien; er wordt louter verwacht dat men streeft naar een kwaliteitsvolle zorgverlening, waar tijdigheid een belangrijke indicator vormt. ${ }^{150}$

\subsubsection{Maternale en foetale indicatie}

De indieners van het wetsvoorstel kiezen er duidelijk voor om de inhoudelijke voorwaarden voor latere zwangerschapsafbreking te behouden. Wel wijzigt het wetsvoorstel de bepaling die het mogelijk maakt om na achttien weken (voorheen twaalf weken) de zwangerschap af te breken op foetale indicatie. Voorheen vereiste de bepaling de zekerheid ${ }^{151}$ dat het kind dat zal geboren worden, zal lijden aan een uiterst zware en ongeneeslijke kwaal. Vanuit verschillende hoeken werd eerder al gesteld dat een dergelijk criterium weinig haalbaar is en de desbetreffende beslissingen veelal voortvloeien uit risico-inschattingen. ${ }^{152}$ De indieners van het wetsvoorstel komen aan deze bedenkingen tegemoet door de vereiste van zekerheid te vervangen door een verwijzing naar een "volgens de huidige stand van de wetenschap groot risico". De indieners van het wetsvoorstel benadrukken hun vertrouwen in de kennis van de arts van de huidige stand van de wetenschap en diens bekwaamheid om een zorgvuldige invulling te geven aan het begrip 'groot risico'. Een verdere definiëring van dit begrip door de wetgever zou de taak van de arts eerder bemoeilijken dan verduidelijken, al staat het de professionele medische organisaties vrij om hier medische richtlijnen over te ontwikkelen mocht blijken dat artsen moeilijkheden ervaren bij de interpretatie van het criterium. Dit geldt ook voor het begrip 'uiterst zware en ongeneeslijke kwaal', waar enige professionele richtlijnen welgekomen zijn.

Het wetsvoorstel wijzigt tevens de bepaling die het toelaat om de zwangerschap af te breken na achttien weken op maternale indicatie. Voorheen was dit in de Nederlandstalige versie van de wet mogelijk wanneer het voltooien van de zwangerschap een ernstig gevaar inhoudt voor de gezondheid van de vrouw, waar de Franstalige tekst de voorzetting van de zwangerschap vermeldde als ijkpunt. ${ }^{153}$ Het erratum werd in het recente wetsvoorstel rechtgezet, zodat beide vertalingen melding maken van de 'voorzetting' van de zwangerschap.

150 Artikel 5 Wet Patiëntenrechten; Zie ook 'tijdigheid' als indicator voor kwaliteitsvolle zorg in Vlaams Instituut Kwaliteit van Zorg, 'Het ontwikkelen van evidence-based indicatoren van kwaliteit van zorg in Vlaanderen: een methodologie', 2019, p. 4-6.

151 De letterlijke tekst vereist dat "(...) vaststaat dat het kind dat geboren zal worden, zal lijden aan een uiterst zware kwaal die als ongeneeslijk wordt erkend op het ogenblik van de diagnose." Artikel 2, $5^{\circ}$ Wet Vrijwillige Zwangerschapsafbreking.

152 Parl.St. Kamer 2018-19, nr. 54-3216/3, p. 35, p. 70, p. 130, p. 140; F. De Meyer, 2020, p. 15; T. Vansweevelt, F. De Meyer en K. Van Assche 2018, p. 231-232.

153 Amendement nr. 2 Parl.St. Kamer 2019-20, nr. 55-0158/3, p. 3. Zie hierover ook H. Nys, Medisch recht en handelen, Mechelen: Kluwer 2016, p. 231. 
Ten slotte moet nog worden gewezen op de discussie over het gebrek aan een eindtermijn voor vrijwillige zwangerschapsafbreking in de wetgeving. In de parlementaire debatten voorafgaand aan de wet zwangerschapsafbreking van 1990 rees de vraag of dit betekent dat (medische) abortus mogelijk is tot kort voor de geboorte. ${ }^{154}$ Daarop verdedigden indieners van het wetsvoorstel het standpunt dat het begrip abortus louter zou verwijzen naar een zwangerschapsafbreking vóór de levensvatbaarheid van de foetus, door medici gesitueerd op 24 weken. ${ }^{155}$ De rechtsleer en rechtbanken bleven verdeeld over de toelaatbaarheid van late zwangerschapsafbreking nu de parlementaire opinie het gebrek aan een eindtermijn in de wet tegensprak. ${ }^{156}$ In de parlementaire debatten van 2018 werd het oude parlementaire standpunt niet herhaald, noch tegengesproken. ${ }^{157}$ In de debatten voorafgaand aan het huidige wetsvoorstel benadrukten parlementsleden daarentegen uitdrukkelijk dat in België geen eindtermijn geldt voor medische zwangerschapsafbrekingen op maternale of foetale indicatie. ${ }^{158}$ Volgens hen zou België op dat vlak een juridisch permissievere wetgeving hanteren dan de meeste andere landen. ${ }^{159}$ Dergelijke bevestiging is wenselijk nu bepaalde ernstige aandoeningen bij de foetus slechts met zekerheid kunnen worden vastgesteld na de termijn van levensvatbaarheid. Bovendien sluit dit expliciet parlementair standpunt aan bij de tekst van de wet en de huidige praktijk in de ziekenhuizen. ${ }^{160}$

\subsubsection{Informatieverplichtingen}

Naast de uitbreiding van de termijn en de inkorting van de wachtperiode worden de informatieverplichtingen grondig herwerkt in het licht van het zelfbeschikkingsrecht van de zwangere persoon. Van belang is enerzijds de schrapping van de plicht voor de arts en/of de voorlichtingsdienst om de zwangere vrouw te informeren over de rechten, de bijstand en de voordelen, bij wet en decreet gewaarborgd aan de gezinnen, aan de al dan niet gehuwde moeders en hun kinderen. Ook de informatieplicht inzake adoptie en de opvangmogelijkheden voor het kind, en de voorlichting inzake contraceptiva, worden geschrapt. Anderzijds wordt een meer algemene bepaling geïntroduceerd die de arts of een andere bevoegde persoon van

154 Verslag Parl.St. Senaat BZ 1988, nr. 247-2, p. 148.

155 Ibid.

156 Rechtsleer: F. De Meyer 2020, p. 11-14; G. Genicot, Droit médical et biomédical, Brussel: Larcier 2017, p. 655; H. Nys 2016, p. 231; T. Vansweevelt, 'Abortus', p. 268; N. Colette-Basecqz en N. Blaise, 'L'avortement' in: X, Les Infractions. Vol. III, Brussel: Larcier 2011, p. 46-48; A. Delannay, 'Les homicides et lésions corporelles volontaires' in: X, Les Infractions. Vol. II, Brussel: Larcier 2010, p. 203; A. De Nauw, Inleiding tot het bijzonder strafrecht, Mechelen: Kluwer 2010, p. 132 en p. 200. Rechtspraak: Rb. Eerste Aanleg Brussel 21 april 2004; Rb. Eerste Aanleg Hasselt 16 oktober 2006; Rb. Eerste Aanleg Leuven 6 maart 2013.

157 D. Holzapfel, 'La loi du 15 octobre 2018 relative à l'interruption volontaire de grossesse - Ceci n'est pas une dépénalisation de l'avortement' in : F. Kuty en A. Weyenbergh (eds.), La science Pénal dans tous ses états : Liber Amoricum Patrick Mandouch et Marc Preumont, Brussel : Larcier 2019, p. 219 e.v.; F. De Meyer 2020.

158 Parl.St. Kamer 2019-20, nr. 55-0158/4, p. 48; Parl.St. 2019-20, nr. 55-0158/8, 15. Toch zal foeticide op maternale indicatie bij een levensvatbare foetus moeilijk denkbaar zijn, nu het kind in deze situatie vaak gewenst is en de nodige premature zorg kan worden toegediend.

159 Parl.St. Kamer 2019-20, nr. 55-0158/4, p. 43, p. 47; Parl.St. 2019-20, nr. 55-0158/8, p. 7.

160 F. De Meyer 2020, p. 11-14. 
de instelling verplicht de zwangere persoon voor te stellen zich medisch-psychosociaal te laten begeleiden. ${ }^{161}$ Artikel 2 behoudt de bepaling die stelt dat de vrijwillige zwangerschapsafbreking wordt verricht in een instelling voor gezondheidszorg die een voorlichtingsdienst heeft waar de zwangere vrouw omstandig wordt ingelicht. Ten slotte wordt ook de plicht behouden om te informeren over de onmiddellijke of toekomstige medische risico's van de zwangerschapsafbreking. ${ }^{162}$

De inperking of schrapping van de specifieke informatieverplichtingen in de Wet Vrijwillige Zwangerschapsafbreking is volgens de indieners van het wetsvoorstel gestoeld op twee beweegredenen. Ten eerste zouden sommige van deze bepalingen een betuttelend en stigmatiserend effect hebben op zwangere personen. Ten tweede zouden de algemene waarborgen in het gezondheidsrecht genoeg bescherming bieden inzake geïnformeerde toestemming. Tegenstanders van de wetswijziging meenden echter dat de schrapping van de specifieke informatieplichten de abortuservaring van de zwangere persoon zou bemoeilijken, eerder dan ten goede komen. ${ }^{163}$ Hoewel zij de specifieke informatieplichten verdedigen in het licht van de bescherming van de zwangere persoon, dient deze argumentatie genuanceerd te worden. Hier dient men te erkennen dat, net zoals het geval is voor de verplichte wachtperiode, een grote meerderheid van zwangere personen vastberaden is, ongeacht wettelijke informatieplichten. ${ }^{164}$ Dat een maatregel slechts een positief effect heeft op een beperkt aantal (kwetsbare) zwangere personen hoeft niet te betekenen dat de regel geen nut heeft, nu de kwetsbaarheid van deze personen hun beschermwaardigheid kan versterken. Er moet echter een bijkomende afweging worden gemaakt ten aanzien van de zwangere personen op wie de specifieke informatieverplichtingen een negatieve impact hebben. Een vastberaden zwangere persoon zal de informatieoverdracht mogelijk als stigmatiserend ervaren, maar ook voor personen die zwangerschapsafbreking overwegen op foetale of maternale indicatie kan sprake zijn van een ongewenst effect. Zo lijkt de informatieplicht over adoptie bij een fatale afwijking bij de foetus niet alleen overbodig, maar ook onnodig kwetsend.

Hoewel de specifieke informatieverplichtingen in het licht van hun effect op zwangere personen voer voor discussie blijven, laat het tweede argument van de indieners van het wetsvoorstel minder ruimte voor onenigheid. De medicalisering van vrijwillige zwangerschapsafbreking door de handeling expliciet onder te brengen in het gezondheidsrecht laat geen twijfel meer bestaan over de toepassing van algemene informatieverplichtingen die gelden bij gezondheidszorg. Van groot belang

161 Artikel 2, $6^{\circ}$ in amendement nr. 2 Parl.St. Kamer 2019-20, nr. 55-0158/3.

162 Ibid., artikel 2, $2^{\circ}$, a.

163 Sommige gezondheidszorgverleners sloten zich hierbij aan. Open brief van 750 zorgverleners, "De verdere verruiming van de abortuswet is een brug te ver", De Morgen, 26 november 2019; opinie van S. Brants Stafmedewerker bij Fara, een vzw die luistert, informeert en begeleidt bij zwangerschapskeuzes, "Laat mij dan maar betuttelend zijn", De Standaard, 2 maart 2020.

164 Zie bv. A. Moore e.a., 'What women want from abortion counseling in the United States: a qualitative study of abortion patients in 2008', Social Work in Health Care 2011 vol. 50, nr. 6, p. 424-442; D.G. Foster e.a., 'Attitudes and decision making among women seeking abortions at one U.S. clinic', Perspectives on Sexual and Reproductive Health 2012 vol. 44, nr. 2, p. 117-124. 
hierbij is de Wet Patiëntenrechten. Die bepaalt uitdrukkelijk dat een patiënt recht heeft op alle hem betreffende informatie die nodig is om inzicht te krijgen in zijn gezondheidstoestand en de vermoedelijke evolutie ervan. ${ }^{165}$ Voorts dient de toestemming tot een interventie geïnformeerd te zijn op basis van inlichtingen vanwege de gezondheidszorgbeoefenaar die betrekking hebben op "het doel, de aard, de graad van urgentie, de duur, de frequentie, de voor de patiënt relevante tegenaanwijzingen, nevenwerkingen en risico's verbonden aan de tussenkomst, de nazorg, de mogelijke alternatieven en de financiële gevolgen" ${ }^{166}$ Diezelfde informatieverplichting in de Wet Patiëntenrechten omvat ook andere door de patiënt of de beroepsbeoefenaar relevant geachte verduidelijkingen. Enkel in het geval de wetgever van mening is dat de draagwijdte van deze algemene informatieverplichting ontoereikend is in de context van abortus, zouden specifieke informatieverplichtingen in de Wet Vrijwillige Zwangerschapsafbreking gerechtvaardigd zijn. In dit verband kan trouwens worden vastgesteld dat de indieners van het wetsvoorstel een informatieplicht behouden dewelke reeds gewaarborgd wordt door de Wet Patiëntenrechten, met name de informatieplicht over medische risico's. ${ }^{167}$

In de rechtsleer en rechtspraak is ten slotte een vraag gerezen gerelateerd aan de wettelijke informatieverplichtingen. In een spraakmakende rechtszaak diende de rechter zich uit te spreken over het bestaan van een plicht voor de arts om, ongeacht de zwangerschapsduur, de zwangere persoon in te lichten over de optie om de zwangerschap af te breken na ontdekking van een bijzonder ernstige en ongeneeslijke kwaal bij de foetus. ${ }^{168}$ Waar de rechtbank dergelijke plicht afwees in het licht van de juridische en ethische controverse rond late zwangerschapsafbreking, kan deze o.i. positief worden beantwoord. Ten eerste wordt deze plicht gesteund op de vaststelling dat vrijwillige zwangerschapsafbreking op maternale of foetale indicatie wettelijk is ongeacht de zwangerschapsduur. De gezondheidszorgbeoefenaars dienen niet langer te vrezen dat zij een onwettige behandelingswijze bespreken, mits uiteraard sprake is van een uiterst zware en ongeneeslijke aandoening. Ten tweede verwijzen we naar de voorafgaande analyse die stelt dat de algemene informatieverplichtingen uit de Wet Patiëntenrechten van toepassing zijn op vrijwillige zwangerschapsafbreking. ${ }^{169}$ Artikel 7, §1 van de Wet Patiëntenrechten genereert een plicht voor de beroepsbeoefenaar om de patiënt informatie te verschaffen over zijn gezondheidstoestand. ${ }^{170} \mathrm{Om}$ inzicht te verkrijgen over diens (fysieke of mentale) gezondheidstoestand en de vermoedelijke evolutie ervan, zal de patiënt doorgaans informatie behoeven over de mogelijkheid tot wettige zwangerschapsafbre-

165 Artikel 7, §1 Wet Patiëntenrechten.

166 Artikel 8, §2 Wet Patiëntenrechten.

167 Artikel 2, 2 , a Wet Vrijwillige Zwangerschapsafbreking; Artikel 8, §2 Wet Patiëntenrechten.

168 Rb. Eerste Aanleg Leuven 6 maart 2013, T. Gez. 2017, nr. 2, p. 108-113; K. Van Assche, 'Geoorloofdheid van en informatieplicht over late zwangerschapsafbreking', (noot onder Rb. Leuven 6 maart 2013), T.Gez. 2017, nr. 2, p. 114-121; A. Huygens, 'Late zwangerschapsafbreking en aansprakelijkheid voor ongewenst bestaan', T.Gez. 2011, nr. 3, p. 217-219.

169 Van Assche 2017, p. 114-121; Huygens 2011, p. 217-219.

170 Zie bv. W. Dijkhoffz, 'Het recht op informatie en geïnformeerde toestemming', T.Gez. 2003, nr. 2, p. 104-107. 
king. ${ }^{171}$ Bovendien verplicht de wet de beroepsbeoefenaar om inlichtingen te verstrekken aan de patiënt die betrekking hebben op de mogelijke alternatieven voor de interventie. Zeker nu het wetsvoorstel vrijwillige zwangerschapsafbreking uitdrukkelijk erkent als gezondheidszorg, dient zwangerschapsafbreking als redelijk alternatief op het niet-ingrijpen (in casu het voorzetten van de zwangerschap) te worden beschouwd. ${ }^{172}$ Deze informatieplicht over de mogelijkheid tot zwangerschapsafbreking is o.i. aan de orde wanneer de zwangere persoon blijk geeft van een ongewenste zwangerschap, of wanneer de arts oordeelt dat sprake is van een ernstige medische aandoening zoals omschreven in de Wet Vrijwillige Zwangerschapsafbreking. Andere alternatieven die mogelijk onder het recht op informatie ressorteren betreffen de prenatale zorg, de postnatale zorg, de geïnduceerde vroeggeboorte, de palliatieve zorg of de foetale chirurgie, mits inachtneming van de risico's, doeltreffendheid en slaagkans van de interventie. ${ }^{173}$

Het wettelijk beschermd gewetensbezwaar van de arts mag hem er o.i. niet van ontslaan de zwangere persoon in te lichten over de optie tot zwangerschapsafbreking op medische indicatie, nu dit gewetensbezwaar enkel betrekking heeft op de (medewerking aan de) verrichting van een zwangerschapsafbreking. ${ }^{174}$ De betrokken zorgverlener kan evenmin het gewetensbezwaar inroepen om te weigeren mee te werken aan prenatale testen die bij een ongunstig resultaat tot een afbreking zouden kunnen leiden, daar ook dit o.i. niet kan vallen onder 'medewerking verlenen aan' de zwangerschapsafbreking. ${ }^{175}$

\section{Gewetensbezwaar}

Net zoals in de wetten van 1990 en 2018 waarborgt het nieuwe wetsvoorstel het recht van de gezondheidszorgbeoefenaar om zijn medewerking aan een zwangerschapsafbreking te weigeren. ${ }^{176}$ Nieuw is de toevoeging die bepaalt dat geen enkele arts op grond van een overeenkomst mag worden belet een vrijwillige zwangerschapsafbreking te verrichten. ${ }^{177}$ Dergelijke verbodsclausules worden als niet-ge-

171 Dit is alvast het geval indien de voorzetting van de zwangerschap een ernstig gevaar inhoudt voor de gezondheid van de zwangere persoon. Echter kan het voorleggen van de optie tot afbreking van de zwangerschap ook nodig zijn om inzicht te krijgen in de (evolutie van de) mentale gezondheidstoestand van de zwangere persoon.

172 Dit was volgens enkele auteurs voorheen reeds het geval. Van Assche 2017, p. 118-119; Vansweevelt 2014, p. 223-225; Huygens 2011, p. 217-219; Veys 2006-07, p. 156-158.

173 T. Vansweevelt, De civielrechtelijke aansprakelijkheid van de geneesheer en het ziekenhuis, Antwerpen: Maklu 1992, nr. 356. Inzake informatie over prenatale behandeling, zie Huygens 2011, p. 217.

174 Artikel 2, $7^{\circ}$ Wet Vrijwillige Zwangerschapsafbreking. Ook volgens de organen van de Raad van Europa dienen gewetensvrijheden restrictief geïnterpreteerd te worden. Van Assche 2017, p. 119120; Huygens 2011, p. 218.

175 Vansweevelt 2014, p. 270. Volgens VAN ASSCHE bevrijdt ook de professionele autonomie van de arts hem er niet van de zwangere persoon in te lichten over de optie tot late zwangerschapsafbreking, Van Assche 2017, p. 120-121.

176 De bepaling is nu echter te vinden in een afzonderlijk artikel, wat de thematische consistentie van het wetsvoorstel ten goede komt. Voorheen stond de bepaling inzake gewetensbezwaar immers in het artikel dat de substantieve voorwaarden voor vrijwillige zwangerschapsafbreking opsomt.

177 Artikel 2, $8^{\circ}$ in amendement nr. 2 Parl.St. Kamer 2019-20, nr. 55-0158/3. 
schreven beschouwd. De nieuwe bepaling lijkt de professionele autonomie van de arts ten aanzien van de zorginstelling te bevestigen, die tevens wordt gewaarborgd door diverse gezondheidsrechtelijke bepalingen en de Code van medische deontologie. ${ }^{178}$

In de rechtsleer werd de vraag of instellingen de uitvoering van niet-therapeutische of betwist-therapeutische handelingen binnen de muren kunnen verbieden voorheen uiteenlopend beantwoord. ${ }^{179}$ Het vertrekpunt van die discussie was veelal de vraag of die handelingen medische handelingen zijn. ${ }^{180}$ Door vrijwillige zwangerschapsafbreking expliciet als gezondheidszorg te kwalificeren en als medische handeling te benaderen lijkt de wetgever de discussie enigszins te beslechten. Het lijkt er niettemin op dat arts-bindende verbodsclausules ook vóór het wetsvoorstel reeds werden verworpen. Zelfs in het kader van euthanasie - een handeling die nog niet expliciet als gezondheidszorg werd gekwalificeerd - neemt een groot deel van de rechtsleer vandaag aan dat zorginstellingen de individuele arts niet per overeenkomst kunnen verbieden om een euthanasie uit te voeren. ${ }^{181}$ Er bestaat dus niet zoiets als een afdwingbaar gewetensbezwaar voor de instelling indien een patiënt om een zwangerschapsafbreking verzoekt en een arts van de instelling bereid is om die uit te voeren. De nieuwe bepaling is in die zin een bevestiging van hoe een groot deel van de rechtsleer het gewetensbezwaar interpreteert: als een recht van de individuele zorgverlener en niet van de instelling. ${ }^{182}$ Om enige controverse hierrond te vermijden, heeft de wetgever er echter goed aan gedaan om de verbodsbepaling te verankeren.

178 Artikel 31 Gezondheidszorgberoepenwet; Artikel 4 Kwaliteitswet; Artikel 144-145 Ziekenhuiswet; Artikel 7 Code van Medische Deontologie.

179 Zie over dit onderwerp: S. Tack, Het ethische beleid in verzorgingsinstellingen, Antwerpen: Intersentia 2013, p. 286-309; E. De Keyser, 'Respect voor het zelfbeschikkingsrecht van de patiënt: gevolgen voor de wet betreffende de euthanasie' T. Gez 2005, p. 374; E. De Keyser e.a., 'Euthanasie: Een Medische Handeling of Niet? Een Explorerend Onderzoek', Huisarts Nu 2004 vol.33, nr. 7; T. Goffin, De Professionele Autonomie van de Arts: De Rechtspositie van de Arts in de Arts-Patiëntrelatie, Brugge: Die Keure 2011, p. 27-36; F. Blockx, 'Het misdrijf van onwettige uitoefening van de geneeskunde' in: T. Vansweevelt en F. Dewallens (eds.), Handboek Gezondheidsrecht I, Antwerpen: Intersentia 2014, p. 664-665; Nys 2016, p. 107-108; K. Van Assche, 'Weigering van woonzorgcentrum om euthanasie binnen zijn muren toe te laten, zelfs als een externe arts deze wil uitvoeren' (noot onder Rb. Leuven 29 juni 2016), T.Gez. 2016-17, p. 344-353; S. Tack en T. Balthazar, 'Wettelijk kader voor instellingsbeleid inzake medische beslissingen aan het levenseinde' in: L. Deliens et al. (eds.), Palliatieve zorg en euthanasie in België. Evaluatie van de praktijk en de wetten, Brussel: ASP 2011, p. 61-90; J. Ter Heerdt, 'De civielrechtelijke aansprakelijkheid voor schade ten gevolge van medische experimenten met mensen', Proefschrift UIA-Rechten 1140, 1999.

180 De kwalificatie van abortus als een medische handeling zou een abortusverbod in instellingen strijdig maken met de professionele autonomie van de arts. Er zijn echter ook andere strekkingen die een abortusverbod voor artsen toetsen aan het recht op professionele autonomie, zie bv. Tack 2013, p. 290-309.

181 Tack 2013, p. 309; Delbeke 2012, p. 216; Van Assche 2016-17, p. 344-353; Vansweevelt 2014, p. 270; T. Vansweevelt en F. Dewallens, 'Ziekenhuizen kunnen euthanasie niet verbieden', De Standaard, 11 oktober 2002.

182 Zie bv. E. Delbeke, 'Euthanasie’ in: T. Vansweevelt en F. Dewallens (eds.), Handboek gezondheidsrecht. Volume II. Rechten van patiënten: van embryo tot lijk, Antwerpen: Intersentia 2014, p. 1362; S. Tack 2013, p. 229 en p. 238-240. 
In welke mate een zorginstelling een praktisch, klinisch of ethisch beperkend instellingsbeleid ten aanzien van vrijwillige zwangerschapsafbreking kan voeren is betwist. Deze discussie is nochtans pertinent in het licht van de vooropgestelde uitbreiding van de termijn voor zwangerschapsafbreking op verzoek, die de gewoonlijke praktijk van abortuscentra en ziekenhuizen aanzienlijk kan wijzigen. Tijdens de bespreking van het wetsvoorstel werd aangehaald dat abortuscentra niet over de nodige expertise en/of faciliteiten zouden beschikken om zwangerschapsafbrekingen na twaalf weken te verrichten. Vandaag zijn het de gespecialiseerde abortuscentra die $84 \%$ van de zwangerschapsafbrekingen in België uitvoeren, doch zelden na twaalf weken optreden. ${ }^{183}$ Ziekenhuizen voeren vooral afbrekingen uit op medische indicatie, zowel voor als na de twaalfde week. ${ }^{184}$ In het licht van een mogelijke praktijkwijziging na termijnverlenging dient te worden vermeld dat zorginstellingen vrij zijn om praktisch-organisatorische aspecten te regelen en een algemeen zorgbeleid te voeren, welke de facto de toegang tot de handeling kunnen bemoeilijken. Uit de Gezondheidszorgberoepenwet en de Ziekenhuiswet blijkt alvast dat de zorgvuldigheidsnorm en de structuur en organisatie van de medische activiteit gegronde redenen kunnen zijn om de professionele autonomie van de arts te beperken. ${ }^{185}$ TACK besluit eveneens dat het praktische instellingsbeleid buiten de grenzen van de professionele autonomie valt, maar wel rekening moet houden met de patiëntenrechten. ${ }^{186}$ Een gedeeltelijk verbod op de verrichting van zwangerschapsafbreking zal mogelijk geboden zijn indien expertise, zorgvuldigheid, kwaliteit en/of praktisch-organisatorische waarborgen niet kunnen worden gegarandeerd voor bepaalde zwangerschapsafbrekingen. Mochten de bezorgdheden over expertise gegrond blijken kan dit mogelijk beperkingen rechtvaardigen, in het bijzonder bij gebrek aan overgangsfase voor de inwerkingtreding van de nieuwe wet.

Gezien de ethische geladenheid van abortus is de vraag naar de toelaatbaarheid van een levensbeschouwelijk instellingsbeleid mogelijk nog relevanter. Een beperkend ethisch instellingsbeleid verbiedt de uitvoering van vrijwillige zwangerschapsafbreking, stelt voorwaarden die strikter zijn dan de wettelijk opgelegde voorwaarden of voert bijkomende voorwaarden in - een situatie vergelijkbaar met buitenwettelijke voorwaarden die sommige zorginstellingen laten gelden voor euthanasie. ${ }^{187}$ Meer specifiek zouden zorginstellingen de toegang tot zwangerschapsafbreking kunnen beperken in de tijd en/of naar onderliggende reden. Verschillende auteurs menen dat zorginstellingen zich wel degelijk levensbeschouwe-

183 Gegevens van de Evaluatiecommissie Zwangerschapsafbreking melden dat abortuscentra in 2016 slechts éénmaal optraden na twaalf weken, wegens een aandoening bij de foetus. Evaluatiecommissie Zwangerschapsafbreking, 'Tweejaarlijks verslag 2016-2017', 2018, p. 49.

184 Ibid., p. 23-24, p. 49, p. 56-59.

185 Voor een analyse van deze rechtsgronden, zie S. Tack, 'Recht op (uitvoering van) euthanasie? Instellingsbeleid en de professionele autonomie van de arts', T. Gez. 2012, p. 7-22.

186 Tack 2013, p. 357, p. 584.

187 Zie ook de discussie over de palliatieve filter als additionele, buitenwettelijke voorwaarde in het kader van euthanasie. 
lijk mogen profileren en daartoe ethische beleidsaccenten mogen leggen. ${ }^{188}$ Een ethisch ontradend, beperkend of gedogend beleid past binnen de marges van hun verenigings- en expressiebeleid. Wanneer een zorginstelling een ethisch ontradend beleid zou voeren inzake bepaalde zwangerschapsafbrekingen door bijkomende voorwaarden te stellen of de uitvoering te weigeren, kan dit hoe dan ook nooit de individuele arts binden die bereid is met de nodige zorgvuldigheid en kwaliteitsgarantie de zwangerschapsafbreking binnen de muren van de instelling en binnen de grenzen van de wet te verrichten. ${ }^{189}$ Evenmin mogen de ethische voorschriften van ziekenhuizen de patiëntenrechten in het gedrang brengen. ${ }^{190}$ Een professionele doorverwijzing van de zwangere persoon - zoals de huidige abortuswetgeving reeds verplicht - zal hier van cruciaal belang zijn.

\section{Misdrijf van verhindering}

Het wetsvoorstel wijzigt de bepaling inzake verhindering die door de Wet van 2018 voor het eerst werd ingevoerd. ${ }^{191}$ Die bepaling formuleert strafsancties die van toepassing zijn op de persoon die een zwangere persoon de vrije toegang tot een instelling voor gezondheidszorg die vrijwillige zwangerschapsafbreking uitvoert, probeert te verhinderen. Hoewel deze bepaling ruimte laat voor interpretatie, blijkt uit de parlementaire voorbereidingen voorafgaand aan de Wet van 2018 dat ze betrekking had op fysieke verhindering van de zwangere persoon. ${ }^{192}$ De indieners verruimen in het onderhavige wetsvoorstel de bepaling door te stellen dat het moet gaan om een persoon die 'fysiek' of op 'enigerlei wijze' de toegang tot de instelling voor gezondheidszorg verhindert. ${ }^{193}$

Zoals ook bleek uit de verwoede parlementaire tussenkomsten door tegenstanders van het wetsvoorstel, heeft deze wijziging voor enige verwarring gezorgd. Vooral de bewoordingen op 'enigerlei wijze' stuitten op kritiek, omdat elke niet-fysieke poging tot verhindering hieronder zou kunnen ressorteren. Hoewel de indieners in

188 Tack 2013, p. 160; Delbeke 2012, p. 217; Tack en Balthazar 2011, p. 66; H. J. J. Leenen et. al., Handboek Gezondheidsrecht, Den Haag: Boom juridisch 2017, p. 308; T. Vansweevelt, 'De euthanasiewet: de ultieme bevestiging van het zelfbeschikkingsrecht of een gecontroleerde keuzevrijheid?', T. Gez. 2003-04, p. 369; A. Dierickx, Als sterven 'leven' is ... is helpen sterven dan doden?, T. Strafr. 2003, nr. 2, p. 34, Delbeke 2012, p. 217.

189 Tack 2013, p. 281-353.

190 Ibid., p. 391-447.

191 Art 3, tweede lid Wet Vrijwillige Zwangerschapsafbreking. Vansweevelt, De Meyer en Van Assche, p. 229.

192 Toelichting wetsvoorstel (D. Clarinval e.a.) betreffende de vrijwillige zwangerschapsafbreking, Parl. St. Kamer 2017-18, nr. 54-3216/1, 4.

193 Zie de tekst aangenomen in tweede lezing, Parl.St. Kamer 2019-20, nr. 55-0158/9, p. 5. 
de voorbereidende werken een niet-limitatieve opsomming ${ }^{194}$ gaven van voorbeelden die aansluiten bij de nieuwe omschrijving, vraagt ook de Raad van State om verheldering in haar juridisch advies. ${ }^{195}$ In het bijzonder stelt de Raad van State in vraag of de bepaling een gerechtvaardigde inperking is op het recht op vrije meningsuiting dat gewaarborgd wordt door het EVRM. Wat betreft de draagwijdte van de bepaling, vraagt de Raad van State alvast verheldering aangaande twee specifieke situaties, m.n. de inmenging van de partner van de zwangere persoon enerzijds en de foutieve informatie en persoonlijke meningen anderzijds. De Raad van State benadrukt de mogelijkheid om deze blinde vlekken uit te klaren in de voorbereidende werken. ${ }^{196}$ Tevens verzoekt ze een verantwoording voor de specifieke strafbepaling nu het wetsvoorstel de Gezondheidszorgberoepenwet van toepassing maakt op vrijwillige zwangerschapsafbreking. Immers, artikel $122, \S 1,4^{\circ}$ van die wet luidt reeds: "Het is verboden de regelmatige en normale uitoefening van de geneeskunde of de artsenijbereidkunde door een persoon die aan de vereiste voorwaarden voldoet, door feitelijkheden of geweld te verhinderen of te belemmeren." Ten slotte beveelt de Raad van State aan dat de indieners aantonen in welke mate een gevangenisstraf bij overtreding van de bepaling te rechtvaardigen is. Het Europees Hof voor de Rechten van de Mens stelt namelijk dat een overtreding van een beperking op het recht van vrije meningsuiting louter in "uitzonderlijke omstandigheden" kan leiden tot dergelijke verregaande strafmaatregel. ${ }^{197}$ Tevens wordt het opleggen van een gevangenisstraf in hedendaagse strafrechttheorie algemeen erkend als een ultimum remedium, waardoor een matiging van de opgelegde sanctie in deze context tot een meer billijk resultaat zou leiden. Deze overwegingen zijn des te pertinenter nu de indieners van het wetsvoorstel de bepaling schrappen die stelt dat boek I van het Strafwetboek van toepassing is op de misdrijven opgenomen in de wet. Door die schrapping kunnen immers geen verzachtende omstandigheden meer worden ingeroepen door de persoon die het misdrijf begaat.

De aanbevelingen uit het eerste advies van de Raad van State doen terecht vermoeden dat de voorgestelde formulering en interpretatie van de bepaling te ruim

194 Aangehaalde voorbeelden betreffen het verspreiden van verkeerde informatie; het achterhouden van informatie; het fysiek verhinderen tot de instelling; folders met overdreven, groteske, niet-waarheidsgetrouwe afbeeldingen m.b.t. abortus afgeven aan de ingang van abortuscentra; posters ophangen met foutieve (medische) informatie, zoals "een foetus is levensvatbaar vanaf 10 weken"; publicaties verspreiden die beweren dat abortus maar toegelaten is tot bijvoorbeeld 10 weken omdat de foetus dan levensvatbaar is en men op een later tijdstip in de zwangerschap niet meer terechtkan bij een arts of abortuscentrum; achterhouden van adressen van instellingen van gezondheidszorg die abortus uitvoeren; blokkeren van websites met info over deze instellingen; verspreiden van verzonnen berichten die de artsen of instellingen die abortus uitvoeren in een slecht daglicht stellen; het zich voordoen als een site of informatiekanaal van de overheid, van een officiele instantie of van een instelling waar abortus wordt uitgevoerd om op die wijze onjuiste informatie te verspreiden over bijv. de voorwaarden waaronder abortus kan plaatsvinden; het weigeren door te verwijzen naar een andere arts of instelling; het op de lange baan schuiven van consultaties, zodat de vrouw niet langer een abortus kan laten uitvoeren omdat de maximale termijn overschreden is; het onder druk zetten of bedreigen van een vrouw die tot abortus wil overgaan; etc.

195 Advies RvS van 24 februari 2020 nr. 66.881/AV, Parl.St. Kamer 2019-20, nr. 55-0158/10, p. 17-22.

196 Ibid., p. 19-20.

197 EHRM (GK) 17 december 2004, Cumpana en Mazare t. Roemenië, § 115; EHRM. 3 april 2014, Amorim Giestas en Jesus Costa Bordalo t. Portugal, $§ 36$. 
zijn. ${ }^{198}$ Mede in het licht van de strafrechtelijke aard van de bepaling zou een concretere en/of nauwere omschrijving van het misdrijf meer aansluiten bij het algemeen rechtsbeginsel nulla poena sine lege stricta, dat een duidelijke en voorzienbare strafwet vereist. Zowel voor- als tegenstanders van de versoepeling van de wetgeving dienden daarop amendementen in om tegemoet te komen aan het advies. ${ }^{199}$ Daar deze enige verduidelijking met zich meebrachten, raakte de Raad van State ook in haar tweede advies gelijkaardige punten van kritiek aan. ${ }^{200}$ Een stemming over welke amendementen de voorkeur genieten werd op het moment van schrijven nog niet gehouden.

\section{De opheffing van bijzondere strafsancties}

\subsection{Depenalisering en decriminalisering van abortus}

Het wetsvoorstel heeft tot doel om alle bijzondere strafsancties op te heffen die voorzien zijn bij vrijwillige zwangerschapsafbreking. Zowel voor de arts die de zwangerschapsafbreking uitvoert, als voor de zwangere persoon die de zwangerschapsafbreking ondergaat, zou niet langer worden voorzien in strafsancties indien de zwangerschapsafbreking wordt uitgevoerd buiten de voorwaarden bepaald in artikel 2 van de Wet Vrijwillige Zwangerschapsafbreking. Het voorstel van de wetgever kan hier worden omschreven als depenalisering. ${ }^{201}$ De wetgever behoudt immers de inbreuk, maar sanctionering hiervan vindt niet langer plaats door bijzondere strafbepalingen ${ }^{202}$ maar wel door een ander, in beginsel niet-strafrechtelijk, sanctioneringsmechanisme, zoals het tuchtrecht. ${ }^{203}$

Deze wijzigingen moeten echter ook worden gekaderd binnen het ruimere vraagstuk van de decriminalisering van abortus. Over de invulling van het begrip decriminalisering bestaat geen eensgezindheid. ${ }^{204}$ Decriminalisering kan immers voorko-

198 Zie ook P. Garré, 'Nieuw wetsvoorstel over abortus miskent vrije meningsuiting', De Juristenkrant, 29 april 2020, p. 17.

199 Amendement nr. 26 (dat geen verduidelijking biedt maar louter de oude tekst herstelt); Amendement nrs. 44 en 47.

200 Advies RvS 19 juni 2020, nr. 67.122/AV, p. 17-18.

201 Althans volgens de definitie gehanteerd door C. Van Den Wyngaert, m.m.v. P. Traest en S. Vandromme, Strafrecht en Strafprocesrecht hooflijnen, Antwerpen: Maklu 2017, p. 48; zie ook Vansweevelt, De Meyer en Van Assche 2018, p. (220) 224. Vergelijk echter met de definitie door A. Stevens, C.E. Hughes, S. Hulme en R. Cassidy, 'depenalization, diversion and decriminalization: a realist review and programme theory of alternatives to criminalization for simple drug possession', European Journal of Criminology 2019, p. (1) 3, waarin depenalisering wordt omschreven als de feitelijke opheffing van strafsancties wat dus eerder wijst op een 'gedoogbeleid'.

202 Het 'algemeen strafrecht' blijft onder dit voorstel echter van toepassing.

203 Vansweevelt, De Meyer en Van Assche 2018, p. (220) 224.

204 Zie voor een meer strikte definitie als 'het schrappen van de gesanctioneerde verplichting uit de rechtsorde en niet enkel uit de strafrechtelijke': Vansweevelt, De Meyer en Van Assche 2018, p. 224; Van Den Wyngaert 2017, p. 48. Vergelijk met de definitie in S. Sheldon en K. Wellings, Decriminalising Abortion in the UK: What Would It Mean?, Bristol: Policy Press 2020, p. 3-4; M. Berer 2017, p. 14; S. Sheldon, 'The Decriminalisation of Abortion: An Argument for Modernisation' Oxford Journal of Legal Studies 2016 vol. 36, nr. 2, p. 336; B.A. Arrigo (ed.), Encyclopedia of Criminal Justice Ethics, Los Angeles: SAGE Publications 2014, p. 169-170 en p. 246-248. 
men in verschillende vormen en volledig, dan wel minimaal zijn. ${ }^{205}$ Opdat sprake zou kunnen zijn van enige vorm van decriminalisering, moet minstens een wijziging plaatsvinden van het uitgangspunt inzake de strafbaarstelling van abortus, waarbij abortus na decriminalisering niet langer principieel wordt beschouwd als misdrijf. Het basisprincipe hierbij is dat vrijwillige zwangerschapsafbreking niet langer een zelfstandige grond vormt voor strafbaarstelling. ${ }^{206}$ Meer verregaand omvat decriminalisering de opheffing van alle (bijzondere) strafsancties die gelden voor abortus. ${ }^{207}$ In die zin kan depenalisering worden beschouwd als een onderdeel van decriminalisering. ${ }^{208}$ Decriminalisering kan echter ook ruimer zijn dan enkel het opheffen van strafsancties en betrekking hebben op alle elementen die een bepaalde handeling tot misdrijf maken, zoals substantieve of procedurele restricties. ${ }^{209}$ Aangezien in de Engelstalige literatuur vooral sprake is van decriminalisering en minder van depenalisering, wordt om vergelijking mogelijk te maken verder het begrip decriminalisering gebruikt.

De indieners van het wetsvoorstel willen er door het opheffen van alle bijzondere strafsancties voor zorgen dat 'de strijd om zwangerschapsafbreking daadwerkelijk uit het strafrecht te halen, wordt voortgezet'. ${ }^{210}$ Hiermee wordt verwezen naar de Wet Vrijwillige Zwangerschapsafbreking van 2018. Hoewel de voorbereidende werken anders deden uitschijnen, had de Wet Vrijwillige Zwangerschapsafbreking van 2018 geenszins depenalisering tot gevolg. ${ }^{211}$ De straffen die in de Wet zwangerschapsafbreking van 1990 stonden, werden immers ongewijzigd overgeheveld naar artikel 3 van de Wet Vrijwillige Zwangerschapsafbreking. Het voorstel wil dus verder gaan dan de Wet van 2018 door alle bijzondere strafsancties te schrappen uit de Wet Vrijwillige Zwangerschapsafbreking. Op deze manier wil men 'abortus uit het strafrecht halen' en overgaan tot een 'echte legalisering'. ${ }^{212}$

Ondanks het schrappen van iedere bijzondere strafsanctie wordt in de voorbereidende werken bij het wetsvoorstel gewezen op de mogelijkheid tot sanctionering van de arts die een zwangerschapsafbreking verricht buiten de wettelijke voorwaarden op tuchtrechtelijk, burgerrechtelijk en strafrechtelijk gebied. ${ }^{213}$ Voor de zwangere persoon blijft daarentegen in beginsel geen enkele strafbaarstelling meer bestaan. Er zou volgens de indieners van het voorstel een sterk draagvlak bestaan om vrijwillige zwangerschapsafbreking uit het strafrecht te halen, waarbij onder meer naar een onderzoek van de ULB en de Universiteit Hasselt uit 2018 wordt verwezen. ${ }^{214}$ Uit dit onderzoek zou blijken dat de meeste Belgen ervoor te vinden

205 Zie voor een opsomming van een aantal mogelijke vormen van decriminalisering: British Medical Association 2017, p. 23-24.

206 British Medical Association 2017, p. 23.

207 Wat dus neerkomt op volledige depenalisering.

208 Arrigo (ed.) 2014, p. 246.

209 Sheldon en Wellings 2017, p. 3.

210 Parl.St. 2019, nr. 55-0158/1.

211 Vansweevelt, De Meyer en Van Assche 2018, p. (220) 224.

212 Over het onderscheid tussen legalisering en decriminalisering, zie Berer 2017, p. 16.

213 Verantwoording bij amendement nr. 3 Parl.St. Kamer 2019-20, nr. 55-0158/3, p. 9.

214 Opiniepeiling over de vrijwillige zwangerschapsafbreking in België: www.abortus.be/_nl/meerweten/ doc/Opiniepeiling-vrijwillige-zwangerschapsafbreking-ULB-2018.pdf. 
zijn om vrijwillige zwangerschapsafbreking uit het strafrecht te halen. ${ }^{215}$ Dergelijke conclusie is o.i. eerder kort door de bocht. De vragen van dit onderzoek zijn immers zeer algemeen en eerder onduidelijk opgesteld. Hieruit conclusies trekken is problematisch, zeker in het licht van de ondervraagde personen die mogelijk onvoldoende kennis hebben van de wetgeving inzake vrijwillige zwangerschapsafbreking.

Concreet worden door het wetsvoorstel het eerste en vierde lid ${ }^{216}$ en het derde en vijfde lid ${ }^{217}$ van artikel 3 van de Wet Vrijwillige Zwangerschapsafbreking opgeheven. ${ }^{218}$ Een aantal van de wetsvoorstellen die aan de basis lagen van het hier besproken voorstel hadden eveneens tot doel om alle bijzondere strafsancties voor de arts die de zwangerschapsafbreking uitvoert en de zwangere persoon die om de zwangerschapsafbreking heeft verzocht, uit de Wet Vrijwillige Zwangerschapsafbreking te halen. ${ }^{219}$ Twee van deze voorstellen beoogden echter slechts de strafsancties van toepassing op de zwangere persoon op te heffen. ${ }^{220}$ Één voorstel had noch depenalisering van de zwangere persoon, noch deze van de arts tot doel. ${ }^{221}$

Het wetsvoorstel maakt de Belgische abortuswetgeving door het opheffen van alle strafsancties uniek binnen Europa. Verschillende landen voorzagen voordien reeds niet langer in strafsancties voor de zwangere persoon ${ }^{222}$, maar in geen enkel ander

215 Parl.St. Kamer 2019-20, nr. 55-0158/1, p. 3.

216 Amendement nr. 3 Parl.St. Kamer 2019-20, nr. 55-0158/3, p. 9.

217 Amendement nr. 4 Parl.St. Kamer 2019-20, nr. 55-0158/3, p. 9.

218 Vergelijk met het oorspronkelijk wetsvoorstel waarin verkeerdelijk sprake was van het eerste, het tweede, het derde en het vijfde lid (art. 3 wetsvoorstel Parl.St. Kamer 2019-20, nr. 55-0158/1, p. 7.).

219 Wetsvoorstel tot wijziging van diverse wetsbepalingen teneinde vrijwillige zwangerschapsafbreking niet langer strafbaar te stellen en de uitvoeringsvoorwaarden ervan te versoepelen (DéFi), Parl.St. Kamer 2019, nr. 55-0385/1 (in dit voorstel wordt echter verkeerdelijk naar artikel 3, tweede lid in plaats van het vierde lid verwezen); artikel 7 wetsvoorstel betreffende het schrappen van abortus uit het strafrecht en het actualiseren van de wetgeving inzake vrijwillige zwangerschapsafbreking (PVDA-PTB), Parl.St. Kamer 2019, nr. 55-0458/1.

220 Artikel 3 wetsvoorstel teneinde vrijwillige zwangerschapsafbreking niet langer strafbaar te stellen (Ecolo-Groen), Parl.St. Kamer 2019-20, nr. 55-0614/1; artikel 3 wetsvoorstel tot versoepeling van de voorwaarden om tot een zwangerschapsafbreking over te gaan (sp.a), Parl.St. Kamer 2019-20, nr. 55-676/1. Zie ook het wetsvoorstel betreffende vrijwillige zwangerschapsafbreking (MR), Parl. St. 2019-20, nr. 55-0740/1. Uit de toelichting (p. 5) kan worden afgeleid dat dit voorstel de opheffing van (alle) strafsancties voor de arts beoogt. Vgl. echter met artikel 6 van dit voorstel, waarin strafsancties worden behouden.

221 Wetsvoorstel betreffende de vruchtafdrijving (Open Vld), Parl.St. Kamer 2019-20, nr. 55-652/1.

222 Zo word in Frankrijk (Art. L2222-2 Code de la Santé Publique) en Nederland (art. 15-18 Wet afbreking zwangerschap) enkel de arts bestraft. Bij zwangerschapsafbreking na de levensvatbaarheidsgrens is in Nederland wel bestraffing van de zwangere persoon mogelijk op grond van artikel 82a Sr. In de Verenigde Staten was van bestraffing van de zwangere persoon nooit sprake, zelfs vóór de legalisering van abortus door het U.S. Supreme Court in Roe v. Wade; C. Sanger, About abortion: terminating pregnancy in twenty-first century America, Cambrigde-Massachusetts: The Belknap Press of Harvard University Press 2017, p. 5. 
Europees land wordt ook de arts niet langer strafbaar gesteld. ${ }^{223}$ Zoals verder wordt besproken, moet de afwezigheid van strafsancties voor de arts in het licht van het zogenaamde gemeen strafrecht ook onder het hier besproken wetsvoorstel worden genuanceerd.

De afwezigheid van strafsancties in de wet doet ten eerste vragen rijzen over de reden voor het behoud van een wettelijk kader waarin nog steeds strikte voorwaarden worden gesteld aan de uitvoering van een vrijwillige zwangerschapsafbreking. Decriminalisering betekent echter niet (noodzakelijk) de deregulering van abortus. ${ }^{24}$ Er kan nog steeds worden voorzien in bepaalde beperkingen waarop een deontologische en burgerrechtelijke controle mogelijk is. ${ }^{225}$ In Nieuw-Zeeland en Victoria (Australië) bepaalt de gedecriminaliseerde abortuswetgeving bijvoorbeeld dat de arts (in samenwerking met een tweede arts) bij verzoeken tot late zwangerschapsafbreking ${ }^{226}$ alle omstandigheden in acht neemt om te bepalen of een zwangerschapsafbreking "gepast" is. ${ }^{227}$ Die beoordeling mag volgens deze abortuswetten steunen op relevante medische omstandigheden, alsook op het huidige en toekomstige fysieke, psychologische en sociale welzijn van de zwangere persoon. ${ }^{228}$ In Nieuw-Zeeland verwijst de wetgeving bovendien naar een beoordeling van "klinische gepastheid" van de verzochte late zwangerschapsafbreking in het licht van "alle relevante juridische, professionele en ethische standaarden voor de gezondheidszorgverlener“. ${ }^{229}$ De ruime appreciatiemarge die de medische professie in deze landen krijgt bij het beoordelen van late afbrekingsverzoeken sluit aan bij de vooropgestelde doelstelling om de arts slechts tuchtrechtelijk te vervolgen. Het hier besproken wetsvoorstel behoudt echter strikt geformuleerde en objectiveerbare voorwaarden die de toegang tot zwangerschapsafbreking beperken. Zoals hierna aan bod komt, kan de opheffing van strafsancties tot rechtsonzekerheid leiden wanneer de arts één van die voorwaarden zou schenden.

Daarnaast moet ook worden gekeken naar de doelstelling van de abortuswetgeving en de rol van strafsancties hierin. Bij de totstandkoming van de Abortuswet in 1990 werd verduidelijkt dat deze was gesteund op een evenwicht tussen twee be-

223 In het Verenigd Koninkrijk wordt op dit ogenblik wel een discussie gevoerd over een mogelijke decriminalisering van abortus. Buiten Europa is in verschillende staten in Australië en in Nieuw-Zeeland reeds sprake van verregaande decriminalisering, waarbij louter tuchtrechtelijke sancties kunnen worden opgelegd aan artsen die de wet niet naleven. Zie bv. Abortion Law Reform Act 2008 Victoria (nr. 58 van 2008); Abortion Legislation Act 2020 New Zealand (nr. 6 van 2020); D. Houghton, D, 'The Abortion Legislation Bill: Welcome If Overdue Reforms', New Zealand Women's Law Journal 2019, nr. 3, p. 290-301; Sheldon 2016, p. 334-365.

224 Herring, Jackson en Sheldon 2020, p. 57-76; British Medical Association, 'The removal of criminal sanctions for abortion: BMA Position Paper', 2019, p. 1.

225 British Medical Association 2017, p. 1.

226 In Victoria na 24 weken, in Nieuw-Zeeland na twintig weken.

227 Sectie 7, Abortion Law Reform Act 2008 Victoria (nr. 58 van 2008); Sectie 11 Abortion Legislation Act 2020 New Zealand (nr. 6 van 2020).

228 Sectie 7 (2), Abortion Law Reform Act 2008 Victoria (nr. 58 van 2008); Sectie 11 (1) en (2), Abortion Legislation Act 2020 New Zealand (nr. 6 van 2020). Ook andere Australische staten hebben een gelijkaardige regeling van late zwangerschapsafbreking.

229 Sectie 11 (2) (b) (i), Abortion Legislation Act 2020 New Zealand (nr. 6 van 2020). Daarnaast wordt vermeld dat de gestatieleeftijd van de foetus een element kan zijn in de overweging. 
langen: de bescherming van de zwangere persoon enerzijds en de bescherming van het ongeboren leven anderzijds. ${ }^{230}$ De bescherming van de zwangere persoon kan thans voldoende worden opgevangen via de algemene gezondheidswetten en deontologische regels, aangezien zwangerschapsafbreking vanuit medisch oogpunt niet langer een ingrijpende handeling vormt. ${ }^{231}$ In dit opzicht lijkt decriminalisering dus niet problematisch. Anderzijds heeft de huidige abortuswet ook de bescherming van ongeboren leven tot doel. ${ }^{232}$ Het is niet duidelijk in hoeverre de indieners van dit wetsvoorstel deze doelstelling nog wensen na te streven. Het behoud van de zwangerschapstermijn en inhoudelijke voorwaarden in de wet doet in ieder geval vermoeden dat zij de beschermwaardigheid van het ongeboren leven in sommige omstandigheden willen waarborgen. Vervolgens rijst de vraag of aan deze doelstelling nog voldoende wordt tegemoetgekomen bij de opheffing van alle strafsancties. Grondig onderzoek naar de invloed van strafsancties, en in het verlengde daarvan van (de)criminalisering, op het statuut van ongeboren leven is dan ook aangewezen. Een verdere bespreking hiervan valt echter buiten het bestek van dit artikel.

In het licht van het voorgaande rijst ook de vraag naar de rol van strafsancties bij de mogelijke bescherming van ongeboren leven op basis van fundamentele rechten en vrijheden. Zo werd door de tegenstanders van het wetsvoorstel de vraag gesteld of het opheffen van strafsancties in strijd is met artikel 2 EVRM. ${ }^{233}$ In het kader van onvrijwillige zwangerschapsafbreking, waarbij een derde tegen de wil in van de zwangere persoon onopzettelijk de zwangerschapsafbreking veroorzaakt, zijn hierbij volgens het EHRM geen strafsancties vereist. ${ }^{234}$ Burgerrechtelijk herstel, eventueel gecombineerd met tuchtrechtelijke gevolgen kunnen in dit geval volstaan. ${ }^{235}$ Is er echter sprake van tegenstrijdige belangen tussen zwanger persoon en ongeboren leven, zoals doorgaans het geval is bij vrijwillige zwangerschapsafbreking, dan dient een belangenafweging plaats te vinden. ${ }^{236}$ Het EHRM lijkt i.c. veel belang te hechten aan de vaststelling dat de zwangerschapsafbreking plaatsvond binnen de grenzen van een nationaal wettelijk kader. ${ }^{237}$ De vraag rijst dan ook of nog sprake kan zijn van een evenwicht van belangen indien de zwangerschapsafbreking zou plaatsvinden buiten het wettelijk kader, en voor België dus buiten de

230 Zie bv. Verslag, Parl.St. Senaat BZ 1988, nr. 247-2, p. 21 en Parl.St. Kamer, 1989-90, nr. 950/9, p. 100 en 105;

231 Zie ook British Medical Association 2019, p. 2.

232 Van deze doelstelling werd o.i. niet afgeweken met de Wet Vrijwillige Zwangerschapsafbreking van 2018, wat ook blijkt uit het behoud van de verschillende procedurele en inhoudelijke voorwaarden in deze wet.

233 Verslag Parl.St. 2019-20, nr. 55-0158/8, p. 21-22.

234 EHRM 8 juli 2004, nr. 53924/00, Vo t. Frankrijk, § 87.

235 EHRM 8 juli 2004, nr. 53924/00, Vo t. Frankrijk, § 90.

236 Zie EHRM 5 september 2002, nr. 50490/90, Boso t. Italië (ontvankelijkheidsbeslissing), $§ 1$.

237 EHRM 5 september 2002, nr. 50490/90, Boso t. Italië (ontvankelijkheidsbeslissing), §1. Aan welke voorwaarden dit kader moet voldoen, wordt niet verder verduidelijkt. Het EHRM lijkt hier in ieder geval wel een ruime beoordelingsruimte over te laten aan de lidstaten, waardoor enkel zeer liberale, dan wel zeer strenge abortuswetgeving de toets van het EHRM mogelijk niet zouden doorstaan; Van Grunderbeeck 2003, p. 361; L. Zwaak, 'Right to life (article 2)' in: P. Van Dijk, G. Van Hoof en L. Zwaak (eds.), Theory and practice of the European Convention on Human Rights, Antwerpen: Intersentia 2006, p. (351) 388; Y. Haeck, “Art. 2 Recht op leven” in J. Vandelanotte en Y. Haeck, Handboek EVRM. Deel 2. Artikelsgewijze commentaar. Volume I, Antwerpen: Intersentia 2004, p. (31) 101. 
voorwaarden van artikel 2 Wet Vrijwillige Zwangerschapsafbreking, zonder dat hieraan (straf)sancties zijn verbonden. Of ook in dit geval tuchtrechtrechtelijke of burgerrechtelijke sancties volstaan, kan uit de huidige rechtspraak van het EHRM niet worden afgeleid. ${ }^{238}$ De Raad van State is in ieder geval van oordeel dat het wetsvoorstel door het schrappen van de strafsancties in de Wet Vrijwillige Zwangerschapsafbreking binnen de beoordelingsruimte blijft die aan de wetgever toekomt. ${ }^{239}$

Zoals hierna zal blijken, leidt het opheffen van de specifieke strafsancties in de wet vooral tot een heel aantal vragen. Dit is o.i. nefast in het licht van één van de voornaamste doelstellingen van decriminalisering, namelijk de creatie van een kader waarin zwangerschapsafbreking kan plaatsvinden zonder angst voor vervolging. ${ }^{240}$ Meer nog, door het opheffen van de strafsancties in de huidige wet lijkt de deur open te staan voor (een poging tot) toepassing van andere, niet specifiek op zwangerschapsafbreking gerichte strafsancties, zoals slagen en verwondingen, maar bijvoorbeeld ook kindermoord. Het toepassingsgebied van dit laatste misdrijf vormde in de voorbereidende werken bij de Wet zwangerschapsafbreking van 1990 voer voor discussie, maar wordt vandaag geacht enkel betrekking te hebben op het doden van een kind tijdens of kort na de bevalling. ${ }^{241}$ Het is echter niet ondenkbaar dat deze discussie herleeft indien niet meer wordt voorzien in afzonderlijke strafsancties bij zeer late zwangerschapsafbrekingen, na het bereiken van levensvatbaarheid. Een dergelijke artificiële uitbreiding van het toepassingsgebied van het misdrijf kindermoord zou o.i. noch een juridisch correcte, noch een wenselijke oplossing zijn om het nu gecreëerde strafrechtelijk vacuüm op te vullen. Zoals het euthanasieproces ${ }^{242}$ over de dood van Tine Nys heeft aangetoond, is het echter niet ondenkbaar dat dergelijke discussies tot bij de rechtbank zouden geraken, waardoor het 'recht op abortus' (opnieuw) onder druk kan komen te staan.

\subsection{De arts}

De indieners van het wetsvoorstel willen, zoals vermeld, de sancties van toepassing op de arts uit de wet halen. ${ }^{243}$ De redenering hierbij is dat zwangerschapsafbreking moet worden beschouwd als een louter medische handeling en er hierdoor geen enkele reden is om vast te houden aan specifieke strafsancties jegens de arts. ${ }^{244}$

238 Vergelijk met EHRM 8 juli 2004, nr. 53924/00, Vo t. Frankrijk, § 90 waarbij de nadruk wordt gelegd op het onopzettelijk karakter van de zwangerschapsafbreking bij de beoordeling dat burgerrechtelijk herstel zou volstaan.

239 Advies RvS van 24 februari 2020 nr. 66.881/AV, Parl.St. kamer 2019-20, nr. 55-0158/10, p. 15.

240 British Medical Association 2017, p. 29.

241 Van Assche 2017, p. (114) 117. Zie in dit verband ook het amendement van Cerexhe e.a. om als kindermoord te beschouwen, iedere zwangerschapsafbreking uitgevoerd op een foetus die uit medisch oogpunt levensvatbaar wordt geacht, behalve bij zwangerschapsafbreking wegens maternale of foetale indicatie; Parl.St. Senaat BZ 1988, nr. 47-247/5, p. 6.

242 Hierover o.m. E. Delbeke, 'De huidige euthanasiewet: daar komt moord en doodslag van?', T.Gez. 2019-20, afl. 5, p. (302) 302-305; Y. LELEU. 'L'euthanasie des patients psychiatriques au banc des accusés', J.L.M.B. 2020, 1.

243 Dit betekent concreet de opheffing van artikel 3, eerste en vierde lid Wet Vrijwillige Zwangerschapsafbreking.

244 Verantwoording bij amendement nr. 3 Parl.St. Kamer 2019-20, nr. 55-0158/3, p. 9. 
Decriminalisering van de arts die een zwangerschapsafbreking uitvoert, wordt gesteund op een diep vertrouwen in het medisch beroep en het volstaan van tuchtrechtelijke sancties.

Het opheffen van strafsancties in de Wet Vrijwillige Zwangerschapsafbreking betekent niet dat er geen enkele sanctie meer van toepassing zal zijn op de arts. Artsen die op foutieve of onzorgvuldige wijze een vrijwillige zwangerschapsafbreking uitvoeren, moeten volgens de indieners van het wetsvoorstel worden gesanctioneerd zoals bij iedere andere medische handeling, waarbij het strafrecht slechts een beperkte rol moet spelen. Sanctionering dient in de eerste plaats dan ook plaats te vinden via tuchtrechtelijke toezichts- en sanctioneringsmechanismen van toepassing op iedere medische handeling. Zo zal het opleggen van tuchtsancties mogelijk zijn op grond van artikel 16 Koninklijk besluit 79 van 10 november 1967 betreffende de Orde der artsen. ${ }^{245}$

Verder breidt artikel 10 van het wetsvoorstel in het licht van het voorgaande het toepassingsgebied van de Kwaliteitswet uit naar vrijwillige zwangerschapsafbreking. ${ }^{246}$ De kwaliteitsvereisten voor gezondheidszorg zullen dus integraal van toepassing worden op gezondheidszorgbeoefenaars die vrijwillige zwangerschapsbrekingen verrichten. Wanneer bepaalde wettelijke kwaliteitsvereisten niet worden nageleefd, zal een Federale Commissie bij het Directoraat-generaal Gezondheidszorg van de FOD Volksgezondheid, Veiligheid van de Voedselketen en Leefmilieu toezicht houden op de praktijkvoering in de gezondheidszorg. Deze Toezichtscommissie houdt niet louter toezicht op de naleving van de wettelijke kwaliteitsvereisten, maar ook op de fysieke en psychische geschiktheid van de gezondheidszorgbeoefenaars. Wanneer schendingen van de kwaliteitsvereisten of de geschiktheid worden vastgesteld, kan de minister maatregelen nemen. Naargelang de schending gaat dit over het opleggen van een verbeterplan, het intrekken van het visum of het schorsen van het visum van de gezondheidszorgverlener.

Door artikel 7 van het wetsvoorstel wordt daarnaast ook de Wet Patiëntenrechten van toepassing gemaakt op de verrichting van vrijwillige zwangerschapsafbreking. Deze wet bevat evenmin specifieke strafsancties, maar voorziet wel in toezicht en een klachtenrecht. Binnen het kader van de Wet Patiëntenrechten kan de Federale Commissie "Rechten van de Patiënt" onder andere informatie verzamelen m.b.t. patiëntenrechtelijke aangelegenheden, de toepassing van de rechten evalueren en de minister adviseren. De ombudsdienst bij deze commissie is bevoegd voor de behandeling van klachten van een patiënt in verband met de uitoefening van zijn rechten toegekend door deze wet, indien een lokale ombudsdienst ontbreekt.

Daarnaast worden ook de specifieke strafsancties voorzien in de Gezondheidszorgberoepenwet van toepassing gemaakt. Volgens de Raad van State zou een arts als gevolg hiervan op grond van artikel 122 en volgende van de Gezondheidszorgberoepenwet een sanctie kunnen worden opgelegd indien is voldaan aan de voor- 
waarden gesteld voor de toepassing van die artikelen. ${ }^{247}$ De sancties voorzien in deze bepalingen zijn echter enkel van toepassing op het uitvoeren van een medische handeling door een persoon die hiertoe niet bevoegd is. Op deze sancties kan in beginsel dus geen beroep worden gedaan indien een arts een zwangerschapsafbreking uitvoert buiten de in artikel 2 van de Wet Vrijwillige Zwangerschapsafbreking bepaalde voorwaarden.

De indieners van het wetsvoorstel verduidelijken echter ook dat op een arts die bij het uitvoeren van een zwangerschapsafbreking de wettelijke voorwaarden zou schenden, naast de sancties voorzien in gezondheidswetten, ook het gemeen strafrecht van toepassing zal zijn. Op strafrechtelijk vlak zou de arts kunnen worden vervolgd voor het misdrijf slagen en verwondingen op de zwangere persoon (art. 398 Sw. ${ }^{248}$ wanneer de wettelijke voorwaarden niet werden nageleefd. ${ }^{249}$ De vraag rijst of de handeling waardoor de zwangerschap wordt beëindigd in geval van zwangerschapsafbreking kan vallen onder het begrip 'slag' of 'verwonding'. Een slag wordt omschreven als een bruuske schok of een stoot tegen een menselijk lichaam, dat tevens kan worden aangebracht door een voorwerp. ${ }^{250} \mathrm{Bij}$ een vrijwillige zwangerschapsafbreking zal wellicht geen sprake zijn van een slag, maar mogelijk wel van een verwonding. Een verwonding wordt opgevat als elk uitwending of inwendig letsel, hoe licht ook, dat zich kenmerkt door het nalaten van een materieel spoor. ${ }^{251}$ Zo wordt bijvoorbeeld aanvaard dat een inwendige bloeding ${ }^{252}$ of een scheur in weefsel ${ }^{253}$ kan vallen onder het begrip verwonding. Bijzonder opzet, waaronder het oogmerk om te schaden, is geen vereiste. ${ }^{254}$ Zwangerschapsafbreking gaat doorgaans gepaard met lichte of hevige bloedingen, gelijkend op menstruatiebloedingen. Hoewel zwangerschapsafbreking meestal geen blijvende letsels veroorzaakt, zou een arts kort na de ingreep een materiële aantasting kunnen waarnemen van de baarmoederwand en/of een uitgezette baarmoederhalsmond. Uitzonderlijk gaat een zwangerschapsafbreking gepaard met bijwerkingen, zoals infecties of verklevingen in de baarmoeder. In een groot deel van deze gevallen zou er o.i. sprake kunnen zijn van een 'verwonding', al zal de rechter in concreto moeten nagaan of de drempel van 'verwonding' is bereikt.

247 Advies RvS van 24 februari 2020, nr. 66.881/AV, Parl.St. Kamer 2019-20, nr. 55-0158/10, p. 14, nr. 8.2.

248 Eventueel is ook vervolging mogelijk wegens onopzettelijk toebrengen van slagen en verwondingen (art. 418 Sw.); zie algemeen over slagen en verwondingen in het kader van de geneeskunde: F. Swennen, 'Juridische grondslagen van de strafrechtelijke immuniteit van de geneesheer i.h.b. de vereiste van het therapeutisch oogmerk', T. Gez. 1997-98, p. 3-21.

249 Verslag Parl.St. 2019-20, nr. 55-0158/4, p. 53.

250 B. Meganck, 'Opzettelijk doden en opzettelijk toebrengen van lichamelijk letsel' in: X (eds.) Postal Memorialis. Lexicon strafrecht, strafvordering en bijzondere wetten, Mechelen: Wolters Kluwer 2013, p. (o160/01) o160/29.

251 Cass. 18 februari 1987, A.C. 1986-87, nr. 359, 803; RDPC 1987, 689; Cass. 7 oktober 1986, Pas. 1987, I, 144; Cass. 12 april 1983, A.C. 1982-83, nr. 433, 952; Cass. 24 april 1972, RDPC 1971-72, 920.

252 Corr. Tongeren 25 mei 1960, JL 1960-61, 10.

253 Cass. 27 februari 1933, Pas. 1933, I, 141.

254 B. Meganck 2013, p. (o160/01) o160/33. 
Van het misdrijf slagen en verwondingen kan ook sprake zijn indien de zwangere persoon toestemming heeft gegeven tot de zwangerschapsafbreking. De toestemming van het slachtoffer inzake het toebrengen van opzettelijke slagen en verwondingen neemt noch het wederrechtelijk karakter van de feiten, noch de schuld van de dader weg en vormt geen rechtvaardigingsgrond. ${ }^{255}$ In het kader van de beoefening van de geneeskunde wordt aangenomen dat het toebrengen van slagen en verwondingen niet wederrechtelijk is wanneer de gedragingen door de wet worden geduld. ${ }^{256}$ Opdat hieraan zou zijn voldaan, worden in de rechtsleer drie voorwaarden aangehaald. Ten eerste is steeds de vrije en geïnformeerde toestemming van de patiënt vereist. ${ }^{257}$ In het bijzonder bij vrijwillige zwangerschapsafbreking is dit evident en blijkt dit ook uit het behoud van het misdrijf van vruchtafdrijving zonder toestemming in het Strafwetboek (art. 348 Sw.). Daarnaast is vereist dat de medische tussenkomst een legitiem doel nastreeft. Dit betekent dat het doel (impliciet) moet zijn erkend door de wetgever. Dit therapeutisch doel is ruimer dan enkel 'curatieve en preventieve' ingrepen. Men aanvaardt dat ook esthetische ingrepen en bijvoorbeeld sterilisaties zonder medische noodzaak een legitiem doel nastreven. ${ }^{258}$ Het legitieme karakter van een medische tussenkomst moet thans worden beoordeeld in het licht van een ruim en evolutief gezondheidsbegrip. ${ }^{259}$ Vrijwillige zwangerschapsafbreking valt hier, zeker in het licht van het hier besproken wetsvoorstel, dan ook onder. Ten slotte is vereist dat de regels van de geneeskunde werden nageleefd en dat de arts de algemene regels van de voorzichtigheid in acht heeft genomen. ${ }^{260}$ Is enkel aan deze laatste voorwaarde niet voldaan, dan is eventueel vervolging mogelijk op grond van het onopzettelijk toebrengen van letsel (artikelen 418 e.v. Sw). ${ }^{261}$

Het is niet duidelijk of de indieners van het wetsvoorstel de toepassing van dit misdrijf voor ogen hadden bij het uitwerken van het wetsvoorstel. In de toelichting bij het voorstel ${ }^{262}$ en deze bij één van de wetsvoorstellen waarop het huidig wetsvoorstel is gebaseerd ${ }^{263}$, wordt enkel verwezen naar strafrechtelijke vervolging op basis van het gemeen (straf)recht. Dat het misdrijf slagen en verwondingen van

255 Cass. 6 december 2005, nr. AR P.05.0576.N, Arr.Cass. 2005, 2429, nr. 3.1; Swennen 1997-98, p. 8; Dierickx 2006, p. 119.

256 A. De Nauw, 'Misdaden en wanbedriven tegen personen' in: A. De Nauw (ed.), Inleiding tot het bijzonder strafrecht, Mechelen: Kluwer 2010, p. 204; D. Dewandeleer, 'Art. 398 t/m 410 Sw. Opzettelijk doden, niet doodslag genoemd, en opzettelijk toebrengen van lichamelijk letsel' in: X (eds.), Postal Memorialis. Lexicon strafrecht, strafuordering en bijzondere wetten, Mechelen: Wolters Kluwer 2001, p. (o160/108) o160/145-146; I. Casier, S. Gutwirth, W. Distelmans en P. De Hert, 'Rechtszekerheid van de arts bij heelkundige ingrepen en euthanasie', Huisarts Nu mei-juni 2014; 43(3).

257 Zie Brussel 5 april 1991, RGAR 1992, nr. 11.924.

258 Zie hierover Dierickx 2006, p. 138-141.

259 Dierickx 2006, p. 141.

260 Dierickx 2006, p. 143.

261 De Nauw 2010, p. 204.

262 Toelichting bij amendement nr. 3 Parl.St. 2019-20, nr. 55-0158/3, p. 10.

263 Parl.St. Kamer 2019, nr. 55-0385/1, p. 9; Parl.St. 2019-20, nr. 55-0740/1, p. 5. Het is echter niet duidelijk of dit wetsvoorstel de opheffing van (alle) strafsancties voor de arts beoogde: vergelijk met artikel 6 van dit voorstel. 
toepassing zou zijn op vrijwillige zwangerschapsafbreking, komt pas ter sprake in het verslag van de eerste lezing. ${ }^{264}$

Hoewel theoretisch mogelijk, is de (potentiële) toepassing van het misdrijf slagen en verwondingen o.i. problematisch. De vraag rijst of de arts kan worden vervolgd van zodra hij één voorwaarde in de Wet Vrijwillige Zwangerschapsafbreking niet respecteert. Een aantal uitspraken in de voorbereidende werken lijken in ieder geval wel die richting uit te gaan ${ }^{265}$ en ook de Raad van State lijkt deze hypothese te bevestigen. ${ }^{266}$ Dit zou betekenen dat artsen nog steeds strafrechtelijke vervolging riskeren bij het uitvoeren van een zwangerschapsafbreking buiten de wettelijke voorwaarden. In dit geval zouden zelfs gelijkaardige strafsancties van toepassing zijn als deze onder de huidige Wet Vrijwillige Zwangerschapsafbreking. ${ }^{267}$

De opheffing van de strafsancties bij vrijwillige zwangerschapsafbreking is onder meer ingegeven door de intentie vrijwillige zwangerschapsafbreking op gelijke wijze te behandelen als andere medische handelingen. ${ }^{268}$ Van medische handelingen wordt steeds verwacht dat ze voldoen aan een reeks algemene regels en beginselen, waarbij de Wet Patiëntenrechten een belangrijke rol speelt. De enkele, maatschappelijk-medische interventies die door de wetgever werden onderworpen aan bijkomende voorwaarden worden gewoonlijk echter voorzien van afzonderlijke strafsancties die zijn afgestemd op deze voorwaarden. Voorbeelden hiervan zijn de embryowet ${ }^{269}$, de MBV-wet en de wet op de esthetische geneeskunde. De voorgestelde wijzigingen van de Wet Vrijwillige Zwangerschapsafbreking leiden ertoe dat de regulering van vrijwillige zwangerschapsafbreking zich ergens tussen beide wetgevende technieken bevindt, waardoor een inconsistent en onzeker kader wordt gecreëerd voor de artsen die de zwangerschapsafbreking verrichten.

Dit kader strookt o.i. niet met de onderliggende principes van decriminalisering. In landen waar wel sprake is van (volledige) decriminalisering van vrijwillige zwangerschapsafbreking worden, zoals vermeld, door de wet slechts beperkte voorwaarden gesteld aan de uitoefening van een vrijwillige zwangerschapsafbreking, waarbij veel beoordelingsruimte wordt gelaten aan de arts. Het overige wordt geregeld in richtlijnen en protocollen uitgewerkt door de medische sector zelf. Het hier besproken wetsvoorstel voorziet echter nog steeds in dezelfde substantiële zwanger-

264 Verslag Parl.St. 2019-20, nr. 55-0158/4, p. 53 (tussenkomst van Mevrouw Sophie Rohonyi (DéFI) een van de auteurs van het voorstel).

265 Zie verslag Parl.St. 2019-20, nr. 55-0158/4, p. 53 waarin wordt vermeld dat het gemeen strafrecht van toepassing is "indien een arts bij een medische ingreep als zwangerschapsafbreking de bij wet bepaalde voorschriften niet naleeft"; zie ook p. 62 van dit verslag. Zie echter de tussenkomst van de heer Verherstraeten (CD\&V) op p. 63-64.

266 Advies RvS van 24 februari 2020 nr. 66.881/AV, Parl.St. Kamer 2019-20, nr. 55-0158/10, p. 14.

267 Vergelijk de sancties in huidig art. 3, eerste lid Wet Vrijwillige Zwangerschapsafbreking met de sancties voorzien in art. 398 Sw. In geval van voorbedachte rade (art. 398, tweede lid Sw.) geldt dezelfde maximum gevangenisstraf als in huidig artikel 3, eerste lid Wet Vrijwillige Zwangerschapsafbreking.

268 Zie o.m. de toelichting bij het wetsvoorstel: Parl.St. Kamer 2019, nr. 55-0158/1, 4 en vooral de toelichting bij amendement nr. 3 Parl.St. Kamer 2019-20, nr. 55-0158/3, 9. Decriminalisering gaat immers vaak gepaard met medicalisering van abortus.

269 Wet van 11 mei 2003 betreffende het onderzoek op embryo's in vitro, BS 28 mei 2003. 
schapstermijn en strikte voorwaarden die in de huidige Wet Vrijwillige Zwangerschapsafbreking aan bijzondere strafsancties zijn onderworpen. Dit leidt tot een incoherent en artificieel wettelijk kader, waarbij een beroep wordt gedaan op 'meer algemene' strafbepalingen om zo hetzelfde resultaat te bereiken als de toepassing van de huidige strafsancties in de Wet Vrijwillige Zwangerschapsafbreking reeds zou geven.

Door terug te vallen op het misdrijf slagen en verwondingen wordt daarnaast ook niet tegemoetgekomen aan de vraag naar differentiatie in sanctionering naargelang de ernst van overtreding. ${ }^{270}$ Dezelfde sanctie is immers van toepassing zowel bij het overtreden van de zwangerschapstermijn of de inhoudelijke voorwaarden die na deze termijn gelden, als bij het overtreden van procedurele voorwaarden zoals de wachttermijn en de nog overgebleven informatieverplichtingen.

De indieners van het wetsvoorstel hadden o.i. een keuze moeten maken. Ofwel hadden zij moeten kiezen voor een grondige hervorming van de regulering van vrijwillige zwangerschapsafbreking, waarbij zwangerschapsafbreking werkelijk wordt behandeld als gelijkaardig aan andere medische handelingen. Het vertrouwen in de medische sector waarop de decriminalisering is gestoeld, moet met het oog op de creatie van een coherent en consistent wettelijk kader ook blijken uit de voorwaarden die gelden bij vrijwillige zwangerschapsafbreking. De sector zelf zou dan vervolgens richtlijnen kunnen uitwerken en publiceren waardoor een transparant kader zou ontstaan rond vrijwillige zwangerschapsafbreking. Een voorbeeld hiervan in Vlaamse context is de recent gepubliceerde aanbeveling inzake late zwangerschapsafbreking van de Vlaamse Vereniging voor Obstetrie en Gynaecologie. ${ }^{271}$ Doorgaans heeft België echter, in tegenstelling tot andere landen, geen rijke traditie van transparante en alomvattende medische richtlijnen en protocollen welke vervolgens worden gepubliceerd. ${ }^{272}$ Een andere mogelijkheid had erin kunnen bestaan om de bijzondere strafsancties voor de arts in de wet te behouden, maar hierbij te voorzien in een differentiatie van strafsancties naargelang de overtreding. Deze weg vereist een meer beperkte hervorming van de abortuswetgeving, maar zou wel leiden tot een significant verschil in de praktijk wanneer dit nog steeds gepaard zou gaan met de voorgestelde wijzigingen t.a.v. de wachtperiode, de informatieverplichtingen en de zwangerschapstermijn.

Naast de toepassing van strafsancties benadrukten de indieners van het wetsvoorstel ook de mogelijkheid tot een burgerrechtelijke aansprakelijkheidsvordering.

270 Zie de tussenkomst van S. Tack tijdens de hoorzittingen gehouden naar aanleiding van de Wet Vrijwillige Zwangerschapsafbreking van 2018; Verslag Parl.St. Kamer 2017-18, nr. 54-3216/3, p. 142. Deze problematiek werd ook reeds aangekaart i.v.m. euthanasie. Zie hierover Delbeke 201920, p. (302) 304.

271 VVOG, 'Aanbeveling "Late zwangerschapsafbreking voor ernstige medische condities", beschikbaar op: www.vvog.be/sites/default/files/richtlijnen/klinisch_pad_voor_late_zwangerschapsafbreking finaal_30720.pdf.

272 Vergelijk bv. met de protocollen en de richtlijnen van de Nederlandse Vereniging voor Obstetrie en Gynaecologie; beschikbaar op: www.nvog.nl en de beleidsrichtlijnen van de British Medical Association over abortus in het Verenigd Koninkrijk: www.bma.org.uk/advice-and-support/ethics/ abortion/the-law-and-ethics-of-abortion. 
Dergelijk juridisch verhaal is uiteraard niet nieuw en evenmin ingegeven door de bescherming van een publiek belang, m.n. de bescherming van het ongeboren leven. Indien een schending van de wettelijke voorwaarden van toepassing op vrijwillige zwangerschapsafbreking (hetzij deze in de Wet Vrijwillige Zwangerschapsafbreking, hetzij deze in de algemene regels van toepassing op de gezondheidszorg) schade tot gevolg heeft, en er bestaat een oorzakelijk verband tussen die wetsovertreding en de schade, dan is er een burgerrechtelijk verhaal mogelijk.

In de context van vrijwillige zwangerschapsafbreking lijkt het eerder onwaarschijnlijk, doch niet onmogelijk, dat een persoon die een zwangerschapsafbreking onderging dergelijke vordering zou instellen tegen de persoon die de afbreking verrichte. Deze mogelijkheid zou bijvoorbeeld benut kunnen worden wanneer de arts de zwangere persoon foutieve informatie gaf over de risico's gerelateerd aan haar gezondheid of aan die van de foetus, op basis waarvan de zwangere persoon een zwangerschapsafbreking verzocht. Dit zijn de zogenaamde wrongful abortion vorderingen. ${ }^{273}$

Het burgerrechtelijk verhaal is mogelijk relevanter voor een potentiële vader of meemoeder die (eventueel) morele schade zou lijden als gevolg van een onwettige zwangerschapsafbreking. Opdat burgerrechtelijk verhaal door de potentiële vader of meemoeder mogelijk zou zijn, moet uiteraard zijn voldaan aan de voorwaarden van artikel 1382 BW. Er moet dus sprake zijn van een fout, schade en een oorzakelijk verband tussen beiden.

Van een fout zal in beginsel sprake zijn indien de voorwaarden in artikel 2 Wet Vrijwillige Zwangerschapsafbreking niet werden nageleefd. ${ }^{274}$ Of de potentiële vader of meemoeder vervolgens schade kan leiden door het plaatsvinden van een onwettige abortus is moeilijker te bepalen. Hier rijst de vraag of de potentiële vader of meemoeder schade kan lijden door het verlies van een nog niet geboren kind. Het EHRM ${ }^{275}$ en Grondwettelijk Hof ${ }^{276}$ hebben in dit verband wel reeds erkend dat de potentiële vader of meemoeder een belang heeft bij de voortzetting of onderbreking van de zwangerschap. Dit belang reikt echter niet zo ver dat deze een vetorecht zou verkrijgen in de beslissing tot abortus. ${ }^{277}$ Of het bestaan van dit belang wel kan leiden tot schade indien de abortus plaatsvindt buiten de wettelijke voor-

273 R. Perry en Y. Adar, 'Wrongful abortion: wrong in search of remedy', Yale Journal of Health Policy, Law, and Ethics, 2005 vol 5, p. 507-586.

274 Het louter overtreden van een norm die een bepaalde gedragsregel bevat kan reeds een fout uitmaken; T. Vansweevelt en B. Weyts, Handboek buitencontractueel aansprakelijkheidsrecht, Antwerpen: Intersentia 2009, p. 137. Het is hierbij in beginsel niet relevant wie de bestemmeling is van de bescherming die door de overtreden norm wordt geboden, aangezien de zogenaamde 'theorie van de relatieve onrechtmatigheid' in België geen algemene gelding kent; Vansweevelt en Weyts, 2009, p. 124.

275 Het EHRM was van oordeel dat de potentiële vader sterk getroffen was door de beëindiging van de zwangerschap en daardoor kon worden beschouwd als slachtoffer in de zin van artikel 34 EVRM; EHRM 5 september 2002, nr. 50490/99, Boso t. Italië (ontvankelijkheidsbeslissing).

276 Zie Arbitragehof nr. 39/91, 19 december 1991, 4. B.2. waarin het Hof van oordeel was dat de wetgeving inzake zwangerschapsafbreking van zodanige aard is dat zij het "familiaal level" van de echtgenoot of potentiële vader kan raken.

277 Arbitragehof nr. 39/91, 19 december 1991, 6. B.11. 
waarden is daarentegen een andere vraag, waarop een positief antwoord meer aannemelijk is. ${ }^{278}$ Een verdere studie over de aanwezigheid van schade bij het verlies van een ongeboren kind valt echter buiten het bestek van dit artikel.

Daarnaast moet, zoals vermeld, ook sprake zijn van een oorzakelijk verband. De potentiële vader of meemoeder zal moeten aantonen dat, indien de wet werd gevolgd, de zwangerschapsafbreking niet zou hebben plaatsgevonden en hij of zij de schade dus niet zou hebben geleden. Ook dit zal niet zo eenvoudig zijn. Aangezien de schade bestaat uit het verlies van een ongeboren kind, zal de potentiële vader of meemoeder moeten aantonen dat, indien de fout niet had plaatsgevonden, ook de vrijwillige zwangerschapsafbreking niet zou hebben plaatsgevonden. Dit zou eventueel het geval kunnen zijn bij een zwangerschapsafbreking die wordt uitgevoerd na het verstrijken van de zwangerschapstermijn, zonder dat hiervoor een medische indicatie bestond. Het zal echter moeilijker zijn een oorzakelijk verband aan te tonen wanneer de wachttermijn of informatieverplichting niet werd gerespecteerd. In dit geval is het immers aannemelijk dat de zwangere persoon ook zou zijn overgegaan tot zwangerschapsafbreking indien de fout niet was begaan. Aangezien in geen enkel geval met zekerheid kan worden gezegd dat het niet bestaan van de fout zou hebben geleid tot de afwezigheid van een zwangerschapsafbreking en dus tot de geboorte van een kind, kan de schade van de potentiële vader o.i. hoogstens bestaan in het verlies van een kans op niet-afbreking van de zwangerschap, en in het verlengde hiervan mogelijk in het verlies van een kans op een toekomstig kind.

Het is ten slotte opmerkelijk dat de indieners van het wetsvoorstel het burgerlijk aansprakelijkheidsrecht aanhalen als alternatief voor strafsancties. ${ }^{279}$ De mogelijkheid voor de potentiële vader of meemoeder om bij gebreke van vetorecht via een burgerrechtelijke aansprakelijkheidsvordering alsnog een invloed te kunnen uitoefenen op de beslissing tot zwangerschapsafbreking, lijkt ons moeilijk verenigbaar met een versterking van de bescherming van het zelfbeschikkingsrecht van de zwangere persoon. ${ }^{280}$ Dat gezegd zijnde was de burgerlijke aansprakelijkheidsvordering ook reeds voor dit wetsvoorstel, en ongeacht de aanwezigheid van strafsancties, een theoretisch beschikbare optie.

\subsection{Andere derden dan de arts}

Artikel 9 van het wetsvoorstel ${ }^{281}$ voegt in de Gezondheidszorgberoepenwet een lid toe aan artikel $3, \S 1 .^{282}$ Op grond hiervan zal als onwettige uitoefening van de geneeskunde eveneens worden beschouwd het gewoonlijk verrichten van een vrijwil-

278 Zie in dit verband Vansweevelt en Weyts 2009, p. 651 waarin wordt aangenomen dat ouders schadevergoeding kunnen vorderen voor de schade die zij persoonlijk leiden door het verlies, veroorzaakt door een derde, van een levend maar niet levensvatbaar geboren kind. Naar analogie kan worden beargumenteerd dat dit ook geldt voor het verlies van een geaborteerd en dus niet levend geboren kind. In beide gevallen verkrijgt het kind immers geen rechtspersoonlijkheid.

279 Parl.St. BZ 2019, nr. 55-0385/1, p. 9 (Dit is een van de wetsvoorstellen die mee aan de grondslag ligt van het huidige wetsvoorstel).

280 Ibid.

281 Amendement nr. 13 Parl. St. 2019-20, nr. 55-0158/7, 8.

282 Gecoördineerde wet van 10 mei 2015 betreffende de uitoefening van de gezondheidszorgberoepen 
lige zwangerschapsafbreking door een persoon die niet aan alle in het eerste lid bedoelde voorwaarden beantwoordt. ${ }^{283}$ Met dit laatste worden die personen bedoeld die niet het wettelijk diploma bezitten van doctor in de genees-, heel- en verloskunde of hiervan niet zijn vrijgesteld (art. 3, §1, eerste lid Gezondheidszorgberoepenwet). Het uitvoeren van een vrijwillige zwangerschapsafbreking door een niet-arts wordt hierdoor dus strafbaar gesteld, maar enkel indien er sprake is van het gewoonlijk verrichten van een vrijwillige zwangerschapsafbreking. Het eenmalig verrichten van een zwangerschapsafbreking door een niet-arts wordt op grond van deze bepaling dus niet strafbaar. ${ }^{284}$

Is er wel sprake van het gewoonlijk verrichten van vrijwillige zwangerschapsafbreking door een niet-arts, dan kan aan deze laatste een gevangenisstraf van acht dagen tot zes maanden worden opgelegd en een geldboete van vijfhonderd tot vijfduizend euro (art. 122, $\S 1,1^{\circ}$, eerste lid Gezondheidszorgberoepenwet). De duur van de gevangenisstraf die in dit geval kan worden opgelegd is lager dan deze in het huidige artikel 3, eerste lid Wet Vrijwillige Zwangerschapsafbreking.

Het opleggen van een sanctie op grond van de Gezondheidszorgberoepenwet sluit de toepassing van straffen gesteld bij het Strafwetboek en, in voorkomend geval, de toepassing van tuchtmaatregelen, verder niet uit. De niet-arts die al dan niet gewoonlijk een vrijwillige zwangerschapsafbreking verricht zal dus ook kunnen worden vervolgd wegens slagen en verwondingen. Aangezien in dit geval geen sprake is van een ingreep in het kader van de geneeskunde, leidt deze strafrechtelijk kwalificatie hier in beginsel niet tot problemen.

De vereiste van 'gewoonlijk' verrichten geldt ten slotte niet voor personen die vroeger wegens onwettige uitoefening van de geneeskunde of van de artsenijbereidkunde werden veroordeeld, die een reclamemiddel hebben aangewend om de verboden handelingen te kunnen stellen of die opvallende middelen hebben aangewend of gebruik hebben gemaakt van een titel of van enige benaming, met het doel te doen geloven dat zij wettelijk zijn bevoegd (art. 122, § 2 Gezondheidszorgberoepenwet).

\subsection{De zwangere persoon}

Het opheffen van de strafsancties voor de zwangere personen getuigt van een streven naar maximale autonomie van de zwangere persoon en de de-stigmatisering van vrijwillige zwangerschapsafbreking. De indieners van het wetsvoorstel willen afstappen van strafsancties voor personen die door een beroep te doen op vrijwillige zwangerschapsafbreking gebruik maken van hun "recht om over hun eigen li-

283 Zie ook artikel 3, § 2, tweede lid Gezondheidszorgberoepenwet: "Zonder afbreuk te doen aan de uitoefening van de geneeskunde, wordt als onwettige uitoefening van de geneeskunde beschouwd, het gewoonlijk verrichten door een persoon die het geheel van de voorwaarden gesteld in het eerste lid niet vervult van elke handeling die tot doel heeft, of wordt voorgesteld als tot doel hebbend, het toezicht uit te oefenen op de zwangerschap, op de bevalling of op het postpartum, alsmede elk ingrijpen dat erop betrekking heeft."

284 Zie in dit verband amendement nr. 45 ingediend door de tegenstanders van het voorstel, Parl.St. Kamer 2019-20, nr. 55-0158/11, p. 53. 
chaam te beschikken". Daarnaast moet het opheffen van strafsancties er volgens de indieners van het wetsvoorstel toe bijdragen dat zwangere personen niet langer hun toevlucht zoeken tot zwangerschapsafbreking in het buitenland, dan wel tot illegale zwangerschapsafbreking, uit vrees voor bestraffing in België. ${ }^{285}$

In het licht van de vaak kwetsbare positie van de persoon die de zwangerschapsafbreking vraagt buiten de wettelijke voorwaarden valt deze depenalisering dan ook zeker aan te moedigen. Niettemin rijst ook hier de vraag naar de toepassing van het gemeen strafrecht op de zwangere persoon. Zo wordt in sommige rechtsleer aangehaald dat het niet is uitgesloten dat het slachtoffer van slagen en verwondingen door middel van diens toestemming wordt beschouwd als deelnemer aan het misdrijf. ${ }^{286}$ Om deze mogelijkheid volledig uit te sluiten zou men naar analogie met de Franse wetgeving 287 eventueel uitdrukkelijk in de wet kunnen bepalen dat de persoon die de zwangerschapsafbreking ondergaat nooit strafbaar kan zijn als deelnemer.

Ook het burgerrechtelijk aansprakelijk stellen van de zwangere persoon bij een zwangerschapsafbreking buiten de wettelijke voorwaarden, lijkt weinig kansen te bieden. Naast de hiervoor reeds opgesomde problemen in verband met de aansprakelijkheid van de arts, zal het met betrekking tot de zwangere persoon ook moeilijk zijn om de aanwezigheid van een fout in hoofde van deze laatste aan te tonen. De verplichtingen in de Wet Vrijwillige Zwangerschapsafbreking zijn immers hoofdzakelijk, indien niet uitsluitend, gericht tot de arts. Hierdoor kan niet zomaar worden aangenomen dat de zwangere persoon bij overtreding hiervan een verbod of gebod heeft geschonden en hierdoor een fout heeft begaan.

\section{Besluit}

Het in deze bijdrage besproken wetsvoorstel ter versoepeling van de Abortuswet raakt aan een aantal pijn- en discussiepunten die al enige tijd het abortusdebat beheersen. De voorgestelde wijzigingen komen dus zeker niet uit het niets en geven aanleiding tot een grondige bespreking. Ook wanneer het wetsvoorstel omwille van politieke redenen niet zou worden aangenomen, kan worden voorspeld dat dezelfde punten in de toekomst opnieuw tot discussie zullen leiden. De bespreking hiervan blijft dus ook buiten het kader van dit voorstel bijzonder relevant.

Het wetvoorstel gaat uit van een uitdrukkelijke bevestiging en verruiming van het zelfbeschikkingsrecht van de zwangere persoon door de toegang tot abortus op verschillende manieren te versoepelen. De verlenging van de zwangerschapstermijn heeft tot gevolg dat de keuze van de zwangere persoon op grond van diens

285 Parl.St. Kamer, 2019-20, nr. 55-0158/003, p. 10.

286 Zie Dierickx 2006, p. 55 i.v.m. slagen en verwondingen in het kader van SM.

287 Zie artikel L2222-4 Code de la Santé Publique in verband met de bestraffing van het verschaffen van middelen aan een zwangere persoon om zelf een zwangerschapsafbreking uit te voeren, waarin uitdrukkelijk wordt bepaald dat de zwangere persoon zelf nooit als medeplichtig mag worden beschouwd; J. Pradel, M. Danti-Juan, Droit pénal spécial, Parijs: Editions Cujas 2007, p. 55. 
zelfbeschikkingsrecht primeert op de bescherming van het ongeboren leven zolang het verzoek vóór het einde van de achttiende week plaatsvindt. De substantiële voorwaarden die nadien blijven gelden, wijzen erop dat vanaf dit ogenblik de bescherming van het ongeboren leven doorweegt op de autonomie van de zwangere persoon.

Ook het procedureel kader waarin de zwangerschapsafbreking dient plaats te vinden, wordt met het oog op de versterking van het zelfbeschikkingsrecht van de zwangere persoon, door het wetsvoorstel gewijzigd. De inkorting van de wachtperiode en het schrappen van de informatieverplichtingen gaan uit van een groot vertrouwen in de zwangere persoon, maar ook in de zorgverlener en bredere medische sector. Het wetsvoorstel stapt hierdoor af van rigide procedurele voorwaarden en kiest voor een flexibele, meer geïndividualiseerde aanpak op maat van de zwangere persoon. Dit komt tegemoet aan de vaststelling dat de oorzaken van een ongewenste zwangerschap alsook de redenen voor een abortus zeer uiteenlopend en persoonlijk kunnen zijn. Door abortus verder te kwalificeren als gezondheidszorg worden de kwaliteitsgaranties van het algemeen gezondheidsrecht expliciet van toepassing, waarbij het kwaliteitsvol en zorgvuldig handelen van de zorgverlener centraal staat.

Daarnaast heft het wetsvoorstel alle bijzondere strafsancties met betrekking tot vrijwillige zwangerschapsafbreking op. Door het volledig depenaliseren van - tevens onrechtmatige - vrijwillige zwangerschapsafbreking, rijst de vraag of de indieners van het wetsvoorstel voormeld 'evenwicht' tussen het zelfbeschikkingsrecht van de zwangere persoon enerzijds en de bescherming van ongeboren menselijk leven anderzijds nog nastreven en in voorkomend geval voldoende waarborgen. Zo werd tijdens de besprekingen in de Commissie voor Justitie door één van de indieners aangehaald dat in vrijwillige zwangerschapsafbreking 'geen aantasting van het leven wordt gezien, maar wel het recht van de vrouw baas te zijn over het eigen lichaam en zelf over haar kinderwens te beslissen. ${ }^{288}$ In de initiële Wet zwangerschapsafbreking van 1990 en de Wet Vrijwillige Zwangerschapsafbreking van 2018 was het nastreven van dit evenwicht nochtans een expliciete doelstelling. Of deze doelstelling nog wordt bereikt onder de voorgestelde wijzigingen is voer voor discussie. Hoewel het wetsvoorstel, zoals vermeld, het kantelpunt van dit evenwicht opschuift eerder dan het dit evenwicht verwerpt, zet het gebrek aan enig strafrechtelijk rechtsgevolg de theoretische bescherming van het ongeboren leven wel onder druk. Dit vergt echter twee belangrijke nuanceringen.

Ten eerste kadert de depenalisering in een ruimere trend om het strafrecht als een last resort te beschouwen. Kritiek op over-criminalisering, overbevolking van gevangenissen en een gebrek aan implementatie van vooropgestelde strafsancties wezen in het verleden reeds op de limieten van ons strafrecht. Deze discussie sluit tevens aan bij de vraag over zin en onzin van strafsancties. In het bijzonder voor de zwangere persoon zouden strafsancties nauwelijks een maatschappelijk relevante functie vervullen. Of een boete of gevangenisstraf proportioneel is in het licht van 
het mogelijke leed dat een onrechtmatige abortus teweegbrengt bij de zwangere persoon is even twijfelachtig. Ook lijken tuchtrechtelijke sancties voor de arts meer aan te sluiten bij de doelstelling om abortus te gaan erkennen als gezondheidszorg. Het siert de indieners van het wetsvoorstel dan ook dat zij het strafrecht in dit kader in vraag stellen. Ten tweede zal de impact van een de jure depenalisering op de praktijk minimaal zijn. Onderzoek uit Australië en Canada doet vermoeden dat een verregaande decriminalisering niet zal leiden tot een hoger aantal abortussen of een uitstel van abortusbeslissingen. ${ }^{289}$ Ook voor meer illegale zwangerschapsafbrekingen na depenalisering hoeft men niet te vrezen. Artsen handelen hoe dan ook in een institutioneel, tuchtrechtelijk én persoonlijk ethisch normenkader, wat hun bereidheid tot illegale late zwangerschapsafbreking zal beperken. In het licht van vereiste expertise, verhoogde maternale risico's, niet-strafrechtelijke repercussies en een meer algemene onwenselijkheid van onrechtmatige late zwangerschapsafbreking, lijkt een rechtstreeks oorzakelijk verband tussen depenalisering en illegale late abortus onwaarschijnlijk. ${ }^{290}$

Uit onze analyse blijkt niettemin dat voorstanders en tegenstanders van het wetsvoorstel de juridische consequenties van een aantal fundamentele wijzigingen niet volledig hebben geanticipeerd. Zo kwam abortus bij minderjarigen en wilsonbekwamen zelfs niet aan bod in de voorbereidende werken. Het uitdrukkelijk onderbrengen van abortus onder de Wet Patiëntenrechten kan echter aanleiding geven tot verregaande gevolgen, waardoor een grondige bespreking van dit vraagstuk niet had misstaan.

Ook de (mogelijk nefaste) gevolgen van de voorgenomen depenalisering werden onvoldoende onderzocht. Waar volledige depenalisering van zwangerschapsafbreking op zichzelf een legitieme doelstelling kan nastreven, staat de uitwerking ervan in het wetsvoorstel niet op punt. Ten eerste zou bij volledige depenalisering onduidelijkheid ontstaan over de toepassing van het misdrijf slagen en verwondingen. De toepassing van dit misdrijf op vrijwillige zwangerschapsafbreking is, hoewel in theorie mogelijk, een merkwaardig alternatief voor de bestaande strafsancties. Hierbij moet ook voor ogen worden gehouden dat het misdrijf slagen en verwondingen geenszins de bescherming nastreeft van ongeboren leven tegen onrechtmatige zwangerschapsafbreking. De doelstelling van de door het wetsvoorstel opgeheven sancties verschilt dus fundamenteel van deze van het misdrijf slagen en verwondingen. Verder hebben de indieners mogelijk niet geanticipeerd op praktische problemen ten gevolge van een wetswijziging. Mocht het wetsvoorstel opnieuw ter sprake komen, is het aan de wetgever om in overleg met abortuscentra en ziekenhuizen na te gaan waar praktische bezwaren voor problemen kunnen zorgen. Uit dat overleg zal blijken of de wet bijvoorbeeld moet voorzien in een pragmatische zwangerschapstermijn die de meer risicovolle zwangerschapsafbrekingen doet toekomen aan tertiaire ziekenhuizen of vergunde centra. Overleg met de

289 B.R. Johnson Jr, L. Keogh and W.V. Norman, 'What would be the likely impact of decriminalisation on the incidence, timing, provision and safety of abortion' in: S. Sheldon en K. Wellings (eds.), 2020, p. $99-126$.

290 Zie ook S. Sheldon 2016, p. 362-363. 
sector zal tevens aantonen welke vraag er bestaat naar de training en vorming inzake de uitvoering van (hoofdzakelijk latere) abortus. Ten slotte leidt het formuleren van strikte inhoudelijke voorwaarden voor late zwangerschapsafbreking tot een rechtsonzekere situatie, in het bijzonder bij onrechtmatig handelen van de arts. De keuze voor volledige depenalisering had o.i. moeten gepaard gaan met een grondige herziening van de inhoudelijke voorwaarden om over te gaan tot abortus.

Vooral in het licht van dit laatste geeft het wetsvoorstel aanleiding tot een grondige discussie over de rol van de overheid en het strafrecht bij de regulering van vrijwillige zwangerschapsafbreking. Een mogelijke weg is immers de verregaande decriminalisering van abortus, waarbij de sanctionering voornamelijk wordt overgelaten aan de medische sector. Hierbij rijst echter ook de vraag in hoeverre er werkelijk sprake is van een draagvlak voor (gedeeltelijke) decriminalisering of depenalisering van vrijwillige zwangerschapsafbreking. Zo lijkt er toch nog een zekere maatschappelijke steun te vinden voor een theoretische bescherming van foetussen in een later stadium van de zwangerschap, wat gematigde sancties voor de arts kan rechtvaardigen. Dit laatste is op zichzelf niet onverenigbaar met een (verregaande) medicalisering en gedeeltelijke decriminalisering van abortus. De kwalificatie van abortus als gezondheidszorg sluit het behoud van enige regulering en bijbehorende strafsancties immers niet uit. Dergelijke vragen vergen echter een zeer grondige studie en debat waarbij men de discussie over abortus eventueel ook kan kaderen binnen discussies over andere ethisch beladen (niet-therapeutische) medische handelingen, zoals euthanasie en medisch begeleide voortplanting. De decriminalisering van abortus vergt in dit geval dat de uitgangspunten in de huidige abortuswetgeving op fundamentele wijze in vraag worden gesteld en vervolgens mogelijk worden herzien. Het voorstel tot decriminalisering is daarom van een andere orde dan de overige voorgestelde wijzigingen in het wetsvoorstel, zoals de verlenging van de zwangerschapstermijn en de versoepeling van de wachtperiode en informatieverplichtingen. Deze wijzigingen passen immers nog perfect binnen het huidige uitgangspunt van de Wet Vrijwillige Zwangerschapsafbreking, waarbij het zelfbeschikkingsrecht van de zwangere persoon slechts binnen een bepaalde en beperkte periode tijdens de zwangerschap primeert op de bescherming van het ongeboren leven. 